
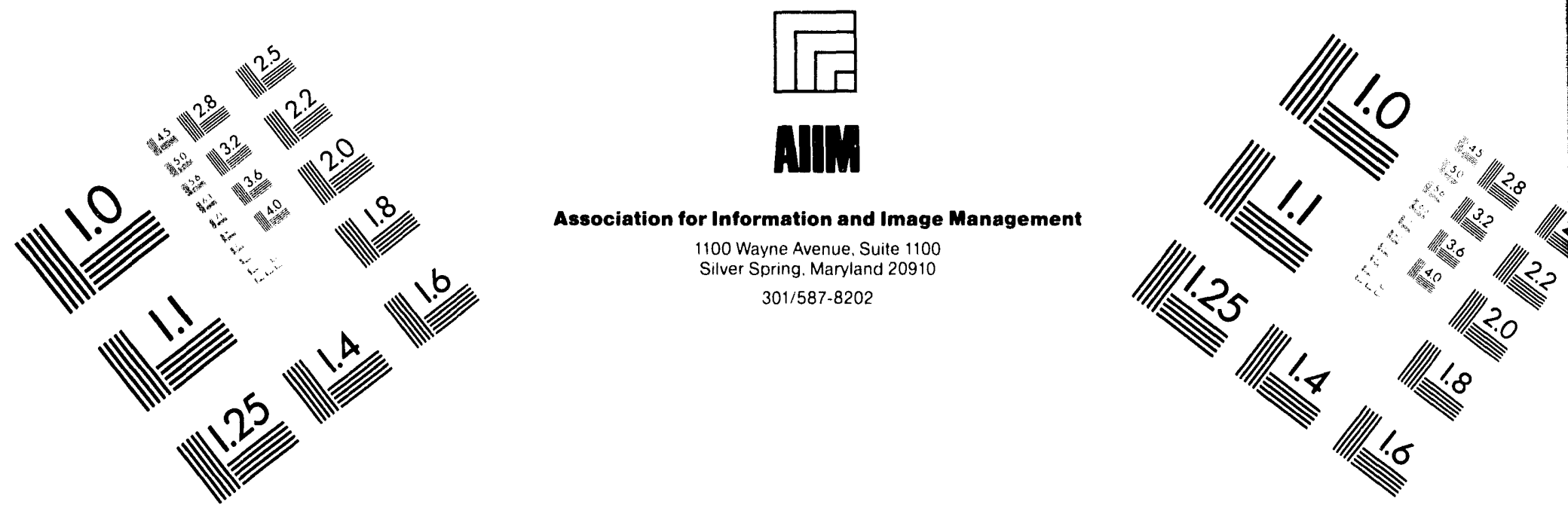

Centimeter

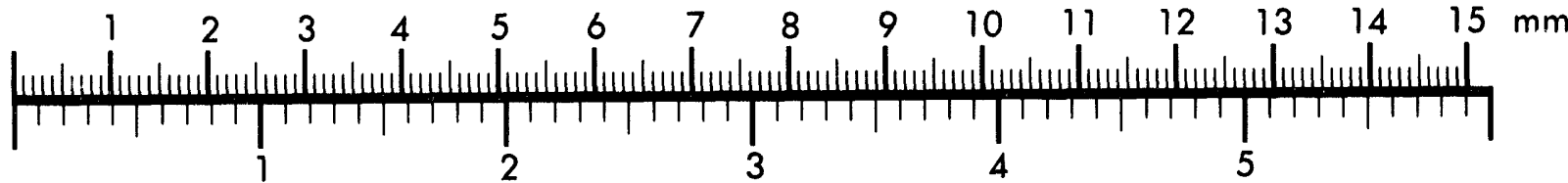
Inches
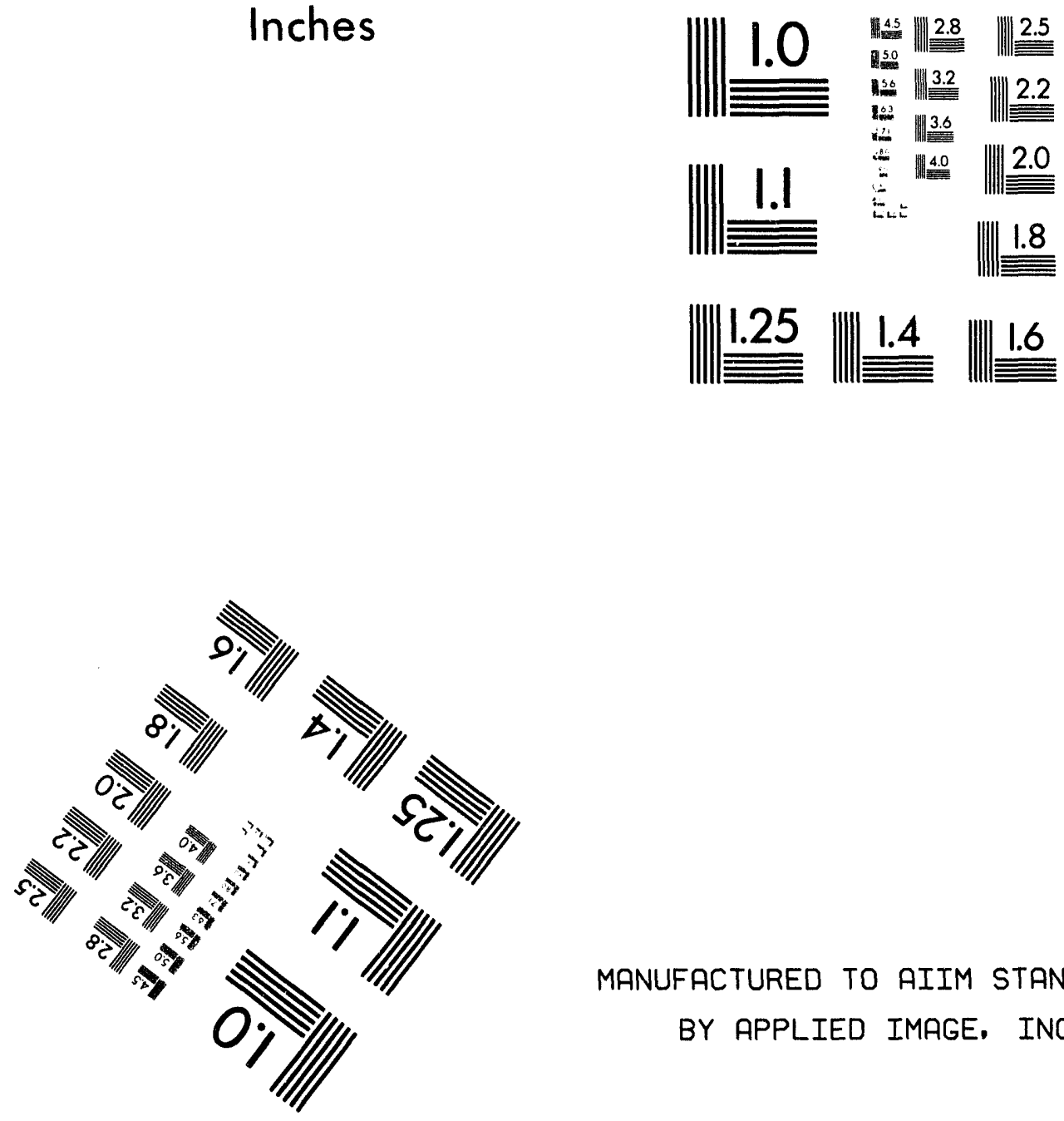

MANUFACTURED TO AIIM STANDARDS

BY APPLIED IMAGE, INC.

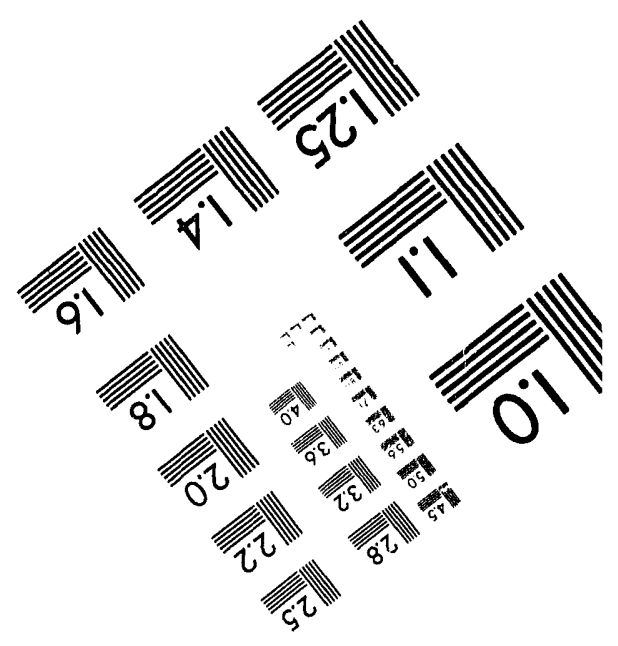



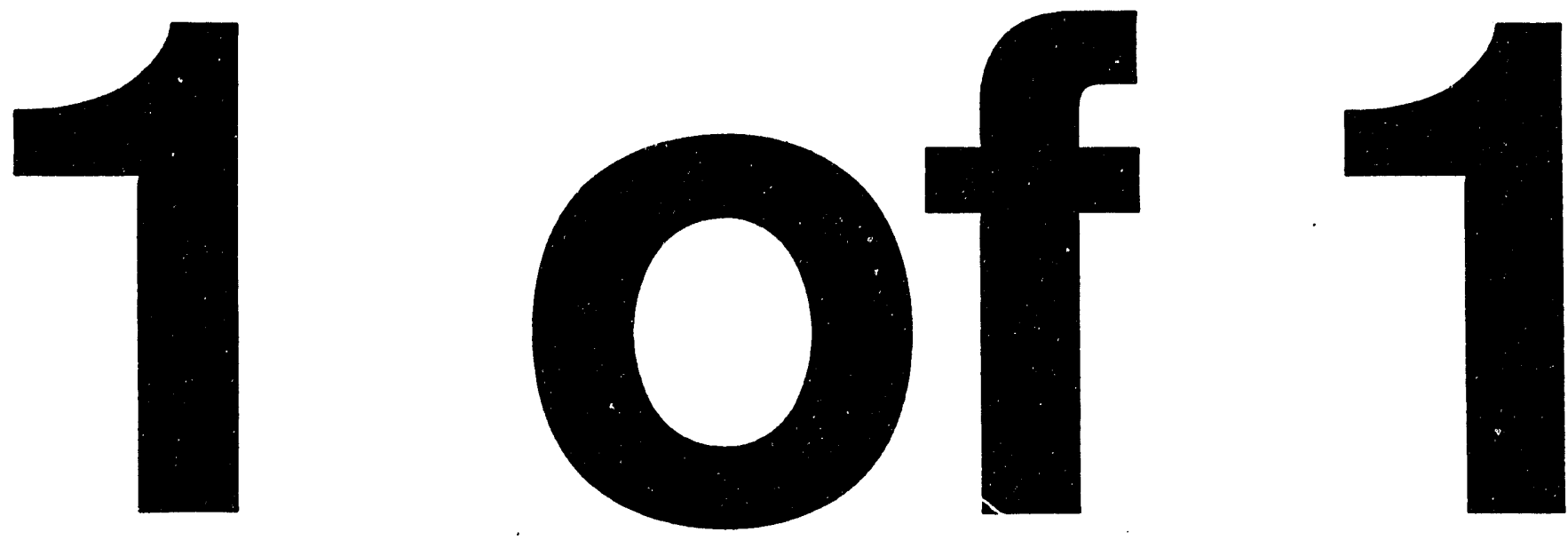

I 
DOE/EIA-0202(94/3Q)

Distribution Category UC-950

\title{
Short-Term Energy Outlook
}

\author{
Quarterly Projections
}

\section{Third Quarter 1994}

\author{
Energy Information Administration \\ Office of Energy Markets and End Use \\ U.S. Department of Energy \\ Washington, DC 20585
}

\footnotetext{
This report was prepared by the Energy Information Administration, the independent statistical and analytical ägency within the Department of Energy. The information contained herein should not be construed as advocating or reflecting any policy position of the Department of Energy or any other organization.
} 
The Short-Term Energy Outlook is prepared by the Energy Information Administration (EIA), Office of Energy Markets and End Use (EMEU). General questions concerning the content of the report may be referred to W. Calvin Kilgore (202-586-1617), Director of EMEU; Arthur Andersen (202-586-1441), Director of Energy Markets and Contingency Information Division; or Derriel Cato (202-586-6574), Chief of the Short-Term Forecasting and Contingency Branch.

Detailed questions may be addressed to David Costello (202-586-1468) or the following analysts:

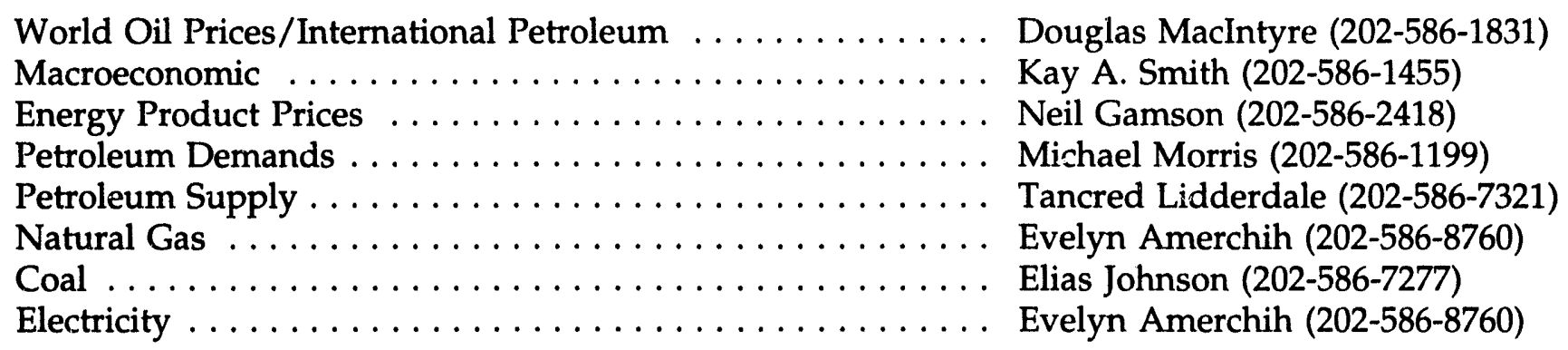

Domestic crude oil production figures are provided by the EIA Dallas Field Office, under the supervision of John H. Wood (214-767-2200). Nuclear electricity generation forecasts are provided by Kenneth Wade (202-254-5514); projections for hydroelectric generation, electricity imports, and utility electricity purchases from nonutilities are provided by Robin Reichenbach (202-254-5353); and coal production, imports, and exports are provided by Byung Doo Hong (202-254-5365)-all of the EIA Office of Coal, Nuclear, Electric and Alternate Fuels. 
The Energy Information Administration (EIA) prepares quarterly, short-term energy supply, demand, and price projections for publication in February, May, August, and November in the Short-Term Energy Outlook (Outlook). An annual supplement analyzes the performance of previous forecasts, compares recent cases with those of other forecasting services, and discusses current topics related to the short-term energy markets. (See Short-Term Energy Outlook Annual Supplement, DOE/EIA-0202.)

The forecast period for this issue of the Outlook extends from the third quarter of 1994 through the fourth quarter of 1995. Values for the second quarter of 1994, however, are preliminary EIA estimates (for example, some monthly values for petroleum supply and disposition are derived in part from weekly data reported in the Weekly Petroleum Status Report) or are calculated from model simulations using the latest exogenous information available (for example, electricity sales and generation are simulated using actual weather data). The historical energy data, compiled into the third quarter 1994 version of the Short-Term Integrated Forecasting System (STIFS) database, are mostly EIA data regularly published in the Monthly Energy Review, Petroleum Supply Monthly, and other EIA publications. Minor discrepancies between the data in these publications and the historical data in this Outlook are due to independent rounding. The STIFS database is archived quarterly and is available from the National Technical Information Service.

The cases are produced using the Short-Term Integrated Forecasting System (STIFS). The STIFS model is driven principally by three sets of assumptions or inputs: estimates of key macroeconomic variables, world oil price assumptions, and assumptions about the severity of weather. Macroeconomic estimates are produced by DRI/McGraw-Hill but are adjusted by EIA to reflect EIA assumptions about the world price of crude oil, energy product prices, and other assumptions which may affect the macroeconomic outlook. The EIA model is available on computer tape from the National Technical Information Service.

\section{Treatment of Petroleum Supply Monthly Reporting Change}

The Energy Information Administration began reporting the series "Motor Gasoline Product Supplied" (equated in this report with gasoline demand) on a new basis for monthly data for January 1993 forward. These new-basis data are included in this issue of the Outlook. The reporting changes reflect data relating to fuel ethanol biended into gasoline as well as certain changes in product classification affecting reported motor gasoline quantities. Beginning with the fourth quarter 1993 edition of the Outlook, any references to data series affected by these changes are, for periods prior to 1993, strictly in terms of the new-basis definition. Thus, history for motor gasoline and miscellaneous product demands was restated so as to make comparisons as consistent as possible. Appendix B from the third quarter 1993 Outlook provides details on the significance of the data restatement. 
Highlights $\ldots \ldots \ldots \ldots \ldots \ldots \ldots \ldots \ldots \ldots \ldots \ldots \ldots \ldots \ldots \ldots \ldots \ldots \ldots \ldots \ldots$

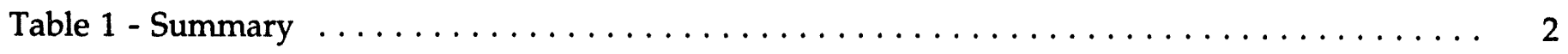

Feature Article

Demand, Supply, and Price Outlook for Reformulated Gasoline, 1995 . . . . . . . . . . 3

The Outlook

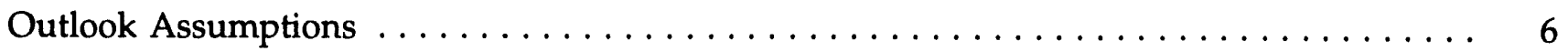

International Oil Demand $\ldots \ldots \ldots \ldots \ldots \ldots \ldots \ldots \ldots \ldots \ldots \ldots \ldots \ldots \ldots$

International Oil Supply $\ldots \ldots \ldots \ldots \ldots \ldots \ldots \ldots \ldots \ldots \ldots \ldots \ldots \ldots$

World Oil Stocks and Net Trade $\ldots \ldots \ldots \ldots \ldots \ldots \ldots \ldots \ldots \ldots \ldots \ldots \ldots \ldots$

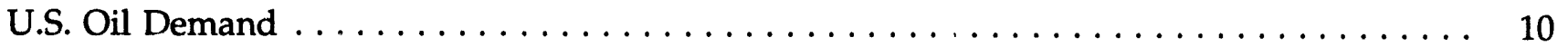

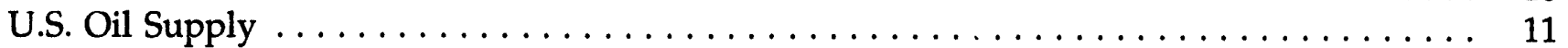

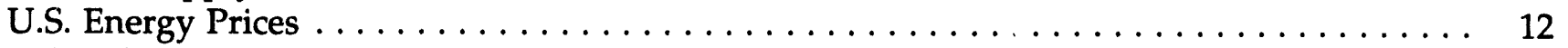

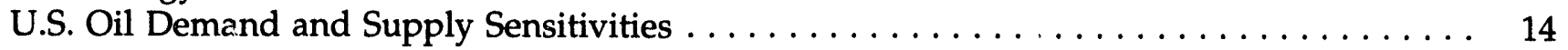

U.S. Natural Gas Demand . . . . . . . . . . . . . . . . . . . . . . . . . 15

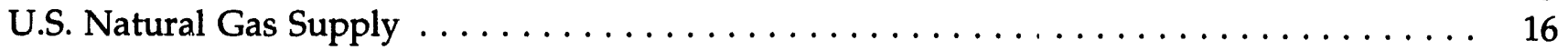

U.S. Coal Demand and Supply $\ldots \ldots \ldots \ldots \ldots \ldots \ldots \ldots \ldots \ldots \ldots \ldots \ldots \ldots \ldots \ldots$

U.S. Electricity Demand and Supply $\ldots \ldots \ldots \ldots \ldots \ldots \ldots \ldots \ldots \ldots \ldots \ldots \ldots$

Tables $2-13 \ldots \ldots \ldots \ldots \ldots \ldots \ldots \ldots \ldots \ldots \ldots \ldots \ldots \ldots \ldots \ldots \ldots \ldots \ldots$

Appendix A

Computation of Petroleum Demand Sensitivities $\ldots \ldots \ldots \ldots \ldots \ldots$

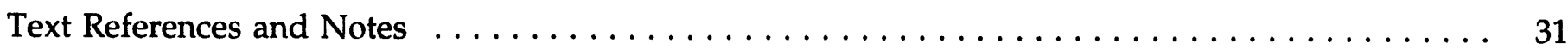

Figure References $\ldots \ldots \ldots \ldots \ldots \ldots \ldots \ldots \ldots \ldots \ldots \ldots \ldots \ldots \ldots \ldots \ldots \ldots \ldots$ 


\section{Contents}

\section{Tables}

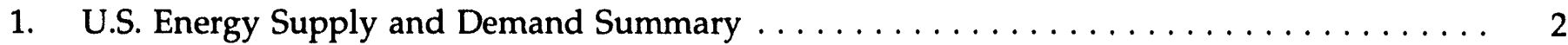

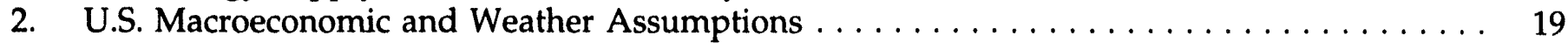

3. U.S. Energy Indicators: Mid World Oil Price Case $\ldots \ldots \ldots \ldots \ldots \ldots \ldots \ldots \ldots \ldots \ldots \ldots \ldots . \ldots 20$

4. International Petroleum Supply and Demand: Mid World Oil Price Case . . . . . . . . . 21

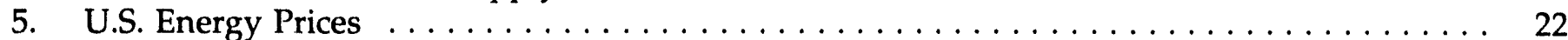

6. U.S. Petroleum Supply and Demand: Low World Oil Price Case . . . . . . . . . . . . . . 23

7. U.S. Petroleum Supply and Demand: Mid World Oil Price Case . . . . . . . . . . . . . . . 24

8. U.S. Petroleum Supply and Demand: High World Oil Price Case . . . . . . . . . . . . . . 25

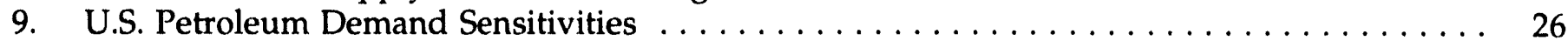

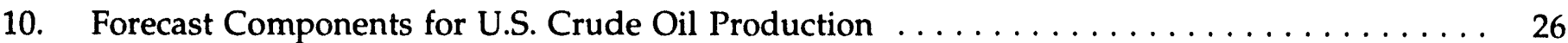

11. U.S. Natural Gas Supply and Demand: Mid World Oil Price Case . . . . . . . . . . . . . . . 27

12. U.S. Coal Supply and Demand: Mid World Oil Price Case . . . . . . . . . . . . . . . . . 28

13. U.S. Electricity Supply and Demand: Mid World Oil Price Case . . . . . . . . . . . . . . . . 29

\section{Figures}

1. U.S. Monthly Crude Oil Prices $\ldots \ldots \ldots \ldots \ldots \ldots \ldots \ldots \ldots \ldots \ldots \ldots \ldots \ldots \ldots \ldots$

2. U.S. Macroeconomic Indicators $\ldots \ldots \ldots \ldots \ldots \ldots \ldots \ldots \ldots \ldots \ldots \ldots \ldots \ldots \ldots \ldots \ldots$

3. World Oil Demand Changes by Region $\ldots \ldots \ldots \ldots \ldots \ldots \ldots \ldots \ldots \ldots \ldots \ldots \ldots \ldots$

4. World Petroleum Demand $\ldots \ldots \ldots \ldots \ldots \ldots \ldots \ldots \ldots \ldots \ldots \ldots \ldots \ldots \ldots$

5. World Oil Production $\ldots \ldots \ldots \ldots \ldots \ldots \ldots \ldots \ldots \ldots \ldots \ldots \ldots \ldots \ldots \ldots \ldots \ldots$

6. OPEC Oil Production and Capacity $\ldots \ldots \ldots \ldots \ldots \ldots \ldots \ldots \ldots \ldots \ldots \ldots \ldots \ldots$

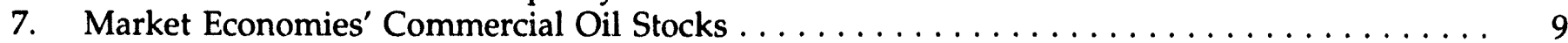

8. FSU Oil Output, Demand, and Net Imports $\ldots \ldots \ldots \ldots \ldots \ldots \ldots \ldots \ldots \ldots \ldots$

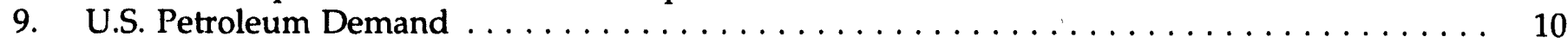

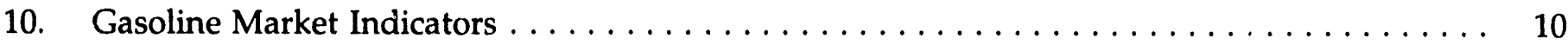

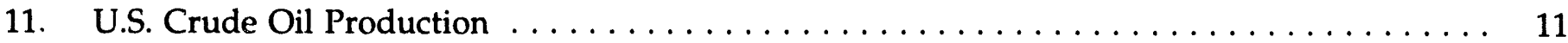

12. U.S. Net Oil Imports' Share of Demand $\ldots \ldots \ldots \ldots \ldots \ldots \ldots \ldots \ldots \ldots \ldots \ldots \ldots \ldots \ldots \ldots \ldots$

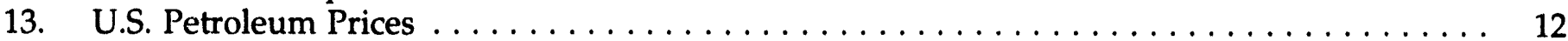

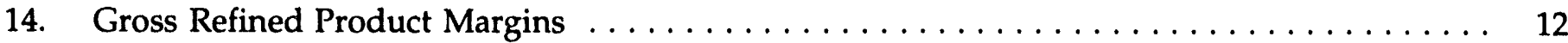

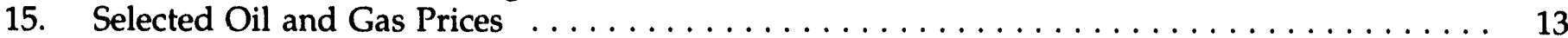

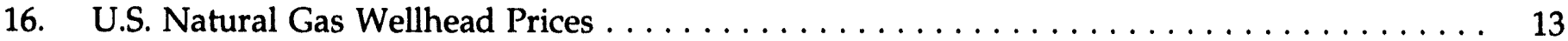

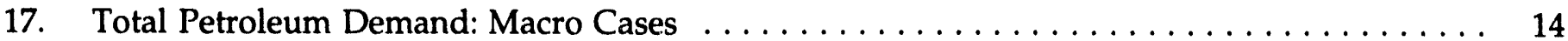

18. Total Petroleum Demand: Weather Cases . . . . . . . . . . . . . . . . . . . . . . . . . . 14

19. U.S. Natural Gas Demand Trends $\ldots \ldots \ldots \ldots \ldots \ldots \ldots \ldots \ldots \ldots \ldots \ldots \ldots \ldots \ldots \ldots \ldots$

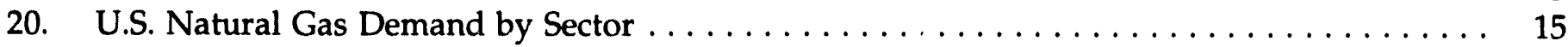

21. U.S. Dry Gas Production and Net Imports $\ldots \ldots \ldots \ldots \ldots \ldots \ldots \ldots \ldots \ldots \ldots \ldots \ldots$

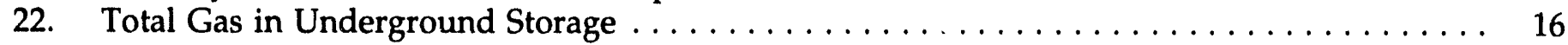

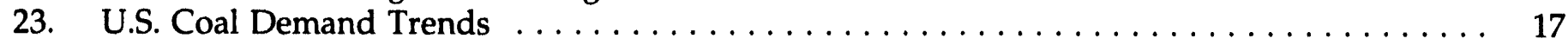

24. Components of U.S. Coal Supply $\ldots \ldots \ldots \ldots \ldots \ldots \ldots \ldots \ldots \ldots \ldots \ldots \ldots \ldots \ldots \ldots$

25. Electricity Demand Changes by Sector $\ldots \ldots \ldots \ldots \ldots \ldots \ldots \ldots \ldots \ldots \ldots \ldots \ldots \ldots$

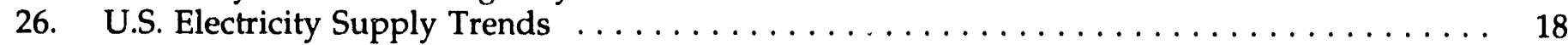


Oil Prices Recover from

Winter Doldrums, With Modest Additional

Increases Expected by 1995

1994, 1995 World Oil

Demand to Rise

Substantially

\section{U.S. Oil Demand \\ in 1994 Boosted by \\ Extreme Winter, \\ Lower Oil Prices}

Natural Gas Demand to Grow Across All Sectors

Coal Production to Rise as Consumption Increases

Electricity Demand Strong on East Coast in 1994, Slows in 1995
The world price of oil, as measured by the average price of oil imported into the United States, has recovered by more than $\$ 2.00$ per barrel from winter levels. Although sharp increases are not expected in the short term, a gradual climb in prices is projected, from the June 1994 average of $\$ 16.00$, to $\$ 18.00$ by the end of 1995 . Because of world supply and demand uncertainties, average import prices could vary at times from as low as $\$ 13.00$ to as high as $\$ 21.00$ over the next 18 months.

World oil demand is expected to rise by about 500,000 barrels per day in 1994 and by more than 700,000 barrels per day in 1995 . Rising oil demand is primarily due to improved economic growth in the Organization for Economic Cooperation and Development (OECD) countries, continued growth in the developing countries, and a reduction in the decline rate of the economies of the former Soviet Union.

In the United States, robust economic growth, lower oil prices and extreme weather patterns during the first half of the year should boost total petroleum demand in 1994 by close to 500,000 barrels per day, or by nearly 3 percent. In 1995, slower economic growth, recovery in product prices and assumed normal weather patterns are expected to slow demand growth to under 100,000 barrels per day.

Natural gas demand in 1994 is expected to grow by almost 5 percent, compared to a little over 3 percent in 1993. This year's growth reaches across all sectors and includes sharp increases due to cold weather during January and February. Underlying demand growth is strong because of increased economic growth and the increasing number of natural gas customers. Despite strong natural gas demand growth, natural gas wellhead price increases are expected to be moderate in 1994.

Coal production is expected to grow by 8.4 percent in 1994, as stocks are replenished and coal consumption increases. Flectricity demand will, of course, be the main impetus to growth in coal demand.

Electric utilities in the Eastern United States, having weathered a difficult winter, have so far faced a blistering summer resulting in an average demand increase of 4.7 percent in the United States as a whole for the first 6 months of 1994. Continued hot weather could alter the general expectation that summer electricity demand will be weak compared to last year's levels. On the other hand, flooding in the Southeastern United States in early July may dampen electricity use noticeably in that region.

Note: The data referenced may be found in Table 1 or in the tables located in the back of this report. 
Table 1. U.S. Energy Supply and Demand Summary

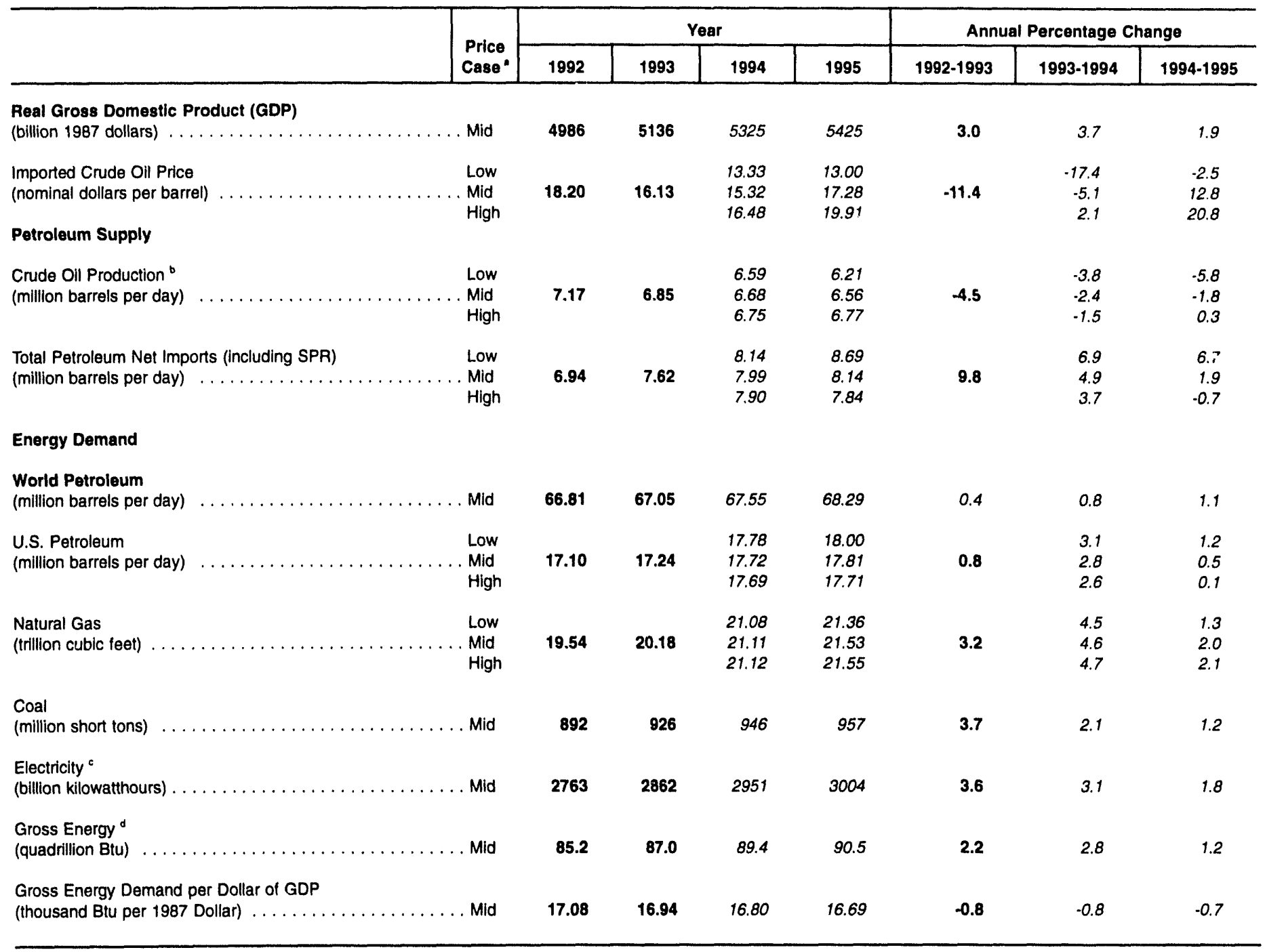

- Refers to the imported cost of crude oil to U.S. refiners assumed for the scenario depicted. In all cases on this table, the mid macroeconomic case and normal weather are used.

Includes lease condensate.

- Refers to utility sales only. Total annual electricity sales for historical periods are derived from the sum of monthly sales figures based on submissions by electric utilities of Form EIA-826, "Monthly Electric Utility Sales and Revenue Report with State Distributions." These historical values differ from annual sales totals based on Form EIA-861, reported in several EIA publications, but match alternate annual totals reported in EIA's Electric Power Monthly, DOE/EIA-0226.

- The gross energy concept shown here is revised to match that presented in Energy Information Administration, Annual Energy Review 1993 (AER), DOEJEIA0384(93), Table 10.1. The conversion from physical units to Btu is calculated using a subset of conversion factors used in the calculations performed for gross energy consumption in Energy Information Administration, Monthly Energy Review (MER). Consequently, the historical data may not precisely match that published in the MER or the AER.

SPA: Strategic Petroleum Resenve.

Notes: Minor discrepancies with other published EIA historical data are due to independent rounding. Historical data are printed in bold, forecasts are in italic. The forecasts were generated by simulation of the Short-Term Integrated Forecasting System.

Sources: Historical data: Energy Information Administration, Monthly Energy Review, DOEJEIA-0035(94/06); Petroleum SUPply Monthly, DOEJEIA-0190(94/06); Petroleum Supply Annual 1993, DOE/EIA-0340(93)/2; Natural Gas Monthly, DOE/EIA-0130(94/06); Electric Power Monthly, DOE/EIA-0226(94/05); and Quarterly Coal Report, DOEJEIA-0121(94/1Q). Macroeconomic projections are based on DRIMcGraw-Hill Forecast CONTROL0694. 


\title{
Demand, Supply, and Price Outlook for Reformulated Gasoline, 1995
}

\author{
by Tancred Lidderdale
}

The reformulated gasoline provisions of the Clean Air Act Amendments of 1990 (CAAA90) require reductions in automobile emissions of ozoneforming volatile organic compounds (VOC) and toxic air pollutants (TAP) in certain areas of the United States. ${ }^{1}$ The new regulations, which go into effect December 1, 1994, mandate the sale of reformulated gasoline in the 9 largest metropolitan areas with the most severe summer ozone levels and other ozone nonattainment areas that opt into the program. The VOC emissions reduction is required only during the summer high ozone season, which lasts from June 1 to September 15 . The TAP emissions reduction requirement applies during the entire year.

The CAAA90 regulations require that reformulated gasoline must meet the following minimum requirements:

- The oxygen content of reformulated gasoline shall equal or exceed 2.0 percent by weight (equivalent to 11.15 percent MTBE or 5.5 percent ethanol by volume).

- The benzene content of reformulated gasoline shall not exceed 1.0 percent by volume.

- Reformulated gasoline shall have no heavy metals, including lead or manganese.

- The emissions of nitrogen oxides $\left(\mathrm{NO}_{\mathrm{x}}\right)$ when using reformulated gasoline shall be no greater than such emissions from 1990 model year automobiles operated on a specified baseline gasoline.

In addition to these minimum requirements, reformulated gasoline must also meet VOC and
TAP emissions reduction targets. The Phase I reformulated gasoline regulations, effective from 1995 to 2000, require a minimum 15 percent reduction in VOC and TAP emissions from 1990 model year automobiles operated on a specified baseline gasoline.

A two-stage approach is taken in implementing the Phase I program. The first stage uses a "simple model" to certify that gasoline meets the VOC and TAP reduction standards. Under the second stage, a "complex model" would supplant the simple model and take effect on January 1, 1998.

The simple model, which relates gasoline composition to the fuel's VOC and TAP emissions, is limited to the effects of gasoline oxygen content, Reid vapor pressure (RVP), and aromatics content. Reformulated gasoline satisfying the above minimum specifications and the following additional composition requirements will meet the Phase I simple model $\mathrm{NO}_{\mathrm{x}}, \mathrm{VOC}$, and TAP emissions performance standards:

- Oxygen: 2.7 percent by weight maximum during summer high ozone season. Maximum 3.5 percent oxygen at other times. States can elect to apply the summer high ozone season 2.7 percent limit during the winter if the use of higher oxygenate levels are found to cause other air quality problems.

- Reid Vapor Pressure: 7.2 psi RVP maximum in southern areas (EPA VOC Control Region 1) and 8.1 psi RVP maximum in northern areas (EPA Region 2), during the high ozone season of June 1 through September 15. RVP controls also apply May 1 through May 31 for facilities 
upstream of retail outlets such as refineries, pipelines, and terminals.

- Aromatics: determined by the emissions model for the required TAP reductions.

- Each refiner's annual average levels of sulfur, olefins, and the temperature at which 90 percent of the fuel vaporizes $\left(\mathrm{T}_{90}\right)$, must not exceed their 1990 averages for these parameters.

Demand for reformulated gasoline is expected to represent almost 35 percent of total motor gasoline demand in 1995. Demand projections for reformulated gasoline are based on the 1990 populations of the participating ozone nonattainment areas and projected per-capita gasoline demands. Corrections are made for "spillover" of reformulated gasoline to areas that will not require reformulated gasoline, changes in automobile fuel efficiency, and the price elasticity of demand.

The minimum oxygenate requirements for reformulated gasoline will increase demand for the oxygenates ethanol, methyl tertiary butyl ether (MTBE), ethyl tertiary butyl ether (ETBE), and tertiary amyl methyl ether (TAME). Aggregate demand is expected to increase from the 1993 average of 319,100 barrels per day of MTBEequivalent volume to an average 480,000 barrels per day of MTBE-equivalent volume in 1995. New oxygenate domestic production capacity and imports should be adequate to satisfy this surge in demand.
The Renewable Oxygenate Standard (ROS) requires that 15 percent of the oxygen content in reformulated motor gasoline in 1995 come from renewables such as corn and other crops (30 percent in 1996 and thereafter). Fuel ethanol and ETBE produced from ethanol are presently the only domestically produced renewable oxygenate gasoline blendstocks. Current ethanol production capacity of over 90 thousand barrels per day should be adequate to supply the approximately 23 thousand barrels per day projected 1995 ethanol requirement under the ROS rule. The capabilities of distribution systems to transport ethanol from producers lorated in the Midwest to the reformulated gasoline market areas in the Northeast, and segregate the greater number of grades and types of gasoline and dyed distillate fuel oils, is being investigated, as firms make final plans for implementing the rule.

Refiners will incur higher operating and capital costs in producing reformulated gasoline. The costs of oxygenate blending, lower gasoline vapor pressure, and reduced benzene and aromatics concentrations are expected to yield a reformulated gasoline wholesale price premium of 3.5 to 4.0 cents per gallon over conventional unleaded gasoline. The retail price premium may be greater due to testing and compliance costs and to the costs of handling and transporting the additional grades of gasoline, which must be segregated in the distribution system. In addition, the wider use of oxygenates, which have a lower energy content than the motor gasoline components they displace, will raise consumers' effective final costs by imposing fuel-economy penalties. 


$$
\begin{aligned}
& \text { 검 } \\
& \text { क } \\
& \text { 을 } \\
& \frac{1}{7} \\
& \overline{0} \\
& \text { 웃 }
\end{aligned}
$$




\section{Outlook Assumptions}

\author{
Figure 1. U.S. Monthly Crucie Oil Prices
}

Sources: Third Quarter 1994 STIFS database and Energy Information Administration, Energy Markets and Contingency Information Division. Details provided in Figure References Section, p. 33.

\section{World Oil Prices}

- Significant price uncertainty surrounds the world oil market, even assuming no Iraqi exports. In the mid-price case, the world oil price, defined as the average cost of imported crude for U.S. refiners, is expected to gradually increase from about $\$ 13$ per barrel in early 1994, to $\$ 18$ by late 1995 (Figure 1).

- The low-price scenario ( $\$ 12$ per barrel, rising to $\$ 13$ per barrel by late 1994) assumes that world demand growth is minimal due to the continuation of a worldwide recession and oversupplied oil markets.

- The high-price scenario (world oil price increases to $\$ 20$ per barrel by late 1995) assumes that world oil demand increases, and/or supply decreases, cause stocks to be drawn down substantially, placing the world oil market in a tight supply situation.

\section{Economic Outlook}

- in 1994, U.S. economic activity is expected to show strong growth early in the year, slowing
Figure 2. U.S. Macroeconomic Indicators
Sources: Third Quarter 1994 STIFS database, U.S. Commerce Department, and Federal Reserve Board. Details provided in Figure References section, p. 33.

later in 1994 and 1995 as increased demand puts pressure on prices and interest rates. Growth in real Gross Domestic Product (GDP) is expected to average 3.7 percent in 1994, and 1.9 percent in 1995 (Figure 2 and Table 2). Uncertainty concerning future short-term macroeconomic growth is examined by modeling alternative growth cases to capture a feasible range of growth rates.

- Much of the 1995 growth slowdown can be explained by investment reactions to rising interest rates early in 1994. Business fixed investment is forecast to increase 11.6 percent in 1994 and 5.2 percent in 1995.

- Manufacturing production increases by 6.1 percent in 1994, slowing to 2.5 percent in 1995 as domestic consumption and investment growth decelerates. Total employment will increase over the forecast.

\section{Weather Assumptions}

- Lower degree-days are implied in 1995 relative to 1994 due to above-normal heating and cooling requirements so far this year. 
Figure 3. World Oil Demand Changes by Region

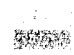

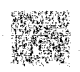

Figure 4. World Petroleum Demand
FSU $=$ Former Soviet Union

Sources: Energy Information Administration, Energy Markets and Contingency Information Division. Details provided in Figure References Section, p. 33.

- World oil demand is expected to rise by about 500,000 barrels per day in 1994 and 730,000 barrels per day in 1995, after increasing by only 240,000 barrels per day in 1993.

- Oil demand in countries belonging to the Organization for Economic Cooperation and Development (OECD) is expected to increase by about 350,000 barrels per day in 1994, due to a 490,000 barrel per day increase in the United States, and by about 320,000 barrels per day in 1995 (mostly outside the United States), when economic performance in the rest of the OECD improves (Figure 3 and Table 4).

- By far the largest area of growth in oil demand is in the developing countries outside the FSU and Eastern Europe (denoted as Asia and Other in Figure 4). After rising by more than 1.1 million barrels per day in 1993, oil demand in Asia and Other countries is expected to rise by about 830,000 barrels per day in 1994, and by another 820,000 barrels per day in 1995. Oil demand in these countries continues to increase substantially
FSU = Former Soviet Union

Sources: Energy Information Administration, Energy Markets and Contingency Information Division. Detalls provided in Figure References Section,, . 33.

each year as their economies continue to grow (Figure 4).

- Oil demand in Asia is expected to increase by about 5 percent in 1994 and 1995. In Latin America, Africa, and the Middle East, oil demand is estimated to grow by 2 to 4 percent in 1994 and $1995 .^{2}$

- After declining by about 1.0 million barrels per day in 1993, oil demand in the FSU and Eastern Europe is expected to decline by about 680,000 barrels per day in 1994, and by roughly 400,000 barrels per day in 1995 (Table 4). As these countries attempt to move toward Western-style economies, oil demand should decline by a smaller amount each succeeding year in the forecast.

- Improved economic growth in the OECD and in the developing countries, along with a reduction in the decline rate in the economies of the FSU, are the major reasons for the 1.2 million barrels per day of world oil demand growth between 1993 and 1995 (Table 4). 


\section{International Oil Supply}

Figure 5. World Oil Production

FSU $=$ Former Soviet Union

Sources: Energy Information Administration, Energy Markets and Contingency Information Division. Details provided in Figure References Section, p. 33.

- After decreasing by 50,000 barrels per day in 1993, world petroleum production is expected to increase by 210,000 barrels per day in 1994, and by 640,000 barrels per day in 1995 (Table $4)$.

- A large share of this increase will come from the Organization of Petroleum Exporting Countries (OPEC). OPEC production is expected to increase by 220,000 barrels per day in 1994, and by 680,000 barrels per day in 1995 (Figure 5).

- Petroleum production in the North Sea is expected to increase by 560,000 barrels per day in 1994, and by another 200,000 barrels per day in 1995. Production by non-OPEC developing countries is expected to rise by 390,000 barrels per day in 1994, and by 400,000 barrels per day in 1995.

- U.S. petroleum production is expected to continue its declining trend throughout the forecast period, falling by 190,000 barrels per day between 1993 and 1995 (Table 4).
Figure 6. OPEC Oil Production and Capacity

Sources: Energy Information Administration, Energy Markets and Contingency Information Division. Detalls provided in Figure References Section, p. 33.

- In the FSU, petroleum production is expected to continue to fall, albeit at a much reduced rate. Following a decline of 1.1 million barrels per day in 1993, production is expected to decline by 900,000 barrels per day in 1994, and by a further 660,000 barrels per day in 1995 (Figure 5 and Table 4).

- While OPEC production is projected to increase significantly in the forecast, rising OPEC production capacity is expected to more than offset increases in production through 1994 (Figure 6).

- OPEC excess production capacity was 2.4 million barrels per day in 1993. It is expected to increase to 3.8 million barrels per day by 1995, as capacity increases outstrip production increases. $^{3}$ A large portion of the estimated increases in OPEC capacity is from Saudi Arabia (1.0 million barrels per day), Kuwait (over 260,000 barrels per day), and Venezuela (nearly 220,000 barrels per day). Iraq could add nearly 2 million barrels per day by end1995 to OPEC capacity if United Nations sanctions were dropped. 
Figure 7. Market Economies' Commercial Oil Stocks

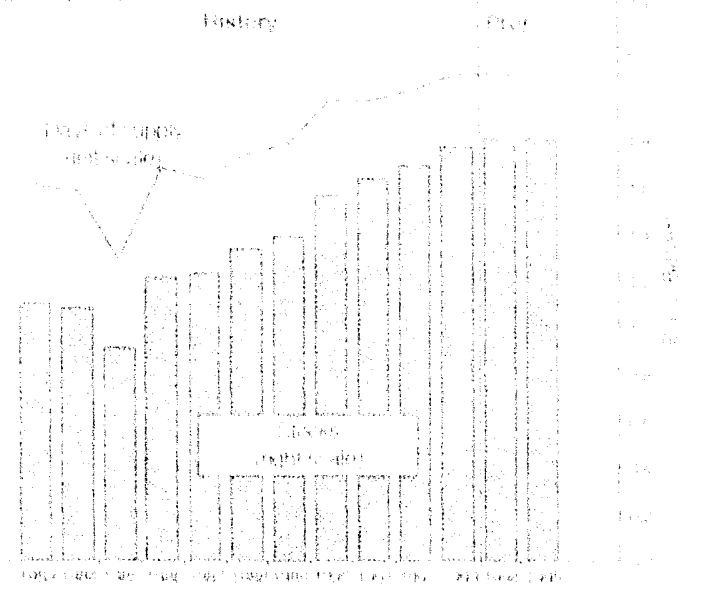

Sources: Energy Information Administration, Energy Markets and Contingency Information Division. Details provided in Figure References Section, p. 33.

- Although petroleum stock levels in the Market Economies (which exclude the former centrally planned economies) have increased each year since 1986, this Outlook projects that stock levels will remain relatively stable in 1994 and 1995 (Figure 7).

- "Days of Supply" is the number of days of consumption that can be supplied by nongovernment stocks above the minimum operating level. Since consumption is expected to increase while stocks are expected to deciine slightly, the "Days of Supply" measure declines in 1994 and 1995. However, this measure would remain at above-average levels.

- The United States contributed to world increases in stock levels with a 4.2 percent increase in (nonstrategic) stocks between yearend 1992 and year-end 1993. ${ }^{4}$ With prices forecast to gradually increase over the next 2
Figure 8. FSU Oil Output, Demand, and Net Exports

Sources: Energy Information Administration. Energy Markets and Contingency Information Division. Detalls provided in Figure Reterences Section, p. 33.

years, there will be some incentive to draw down stocks from current levels.

- Net exports from the FSU are estimated to decline from 2.2 million barrels per day in 1993 to 2.1 million barrels per day in 1994 and 1.8 million barrels per day in 1995 (Figure 8 and Table 4). This reflects the expectation that FSU oil production will decline more rapidly than oil consumption.

- Although exports of petroleum are a major source of hard currency for the FSU, and thus a strong incentive in maintaining exports, expected oil production declines will make it difficult for the FSU to maintain oil exports.

- A change in this situation, such as would occur if consumption in the region stabilized or began to grow again, could add significantly to production requirements in OPEC. The situation in the FSU is one of the main wildcards in the world oil market over the next 2 years. 


\section{U.S. Oil Demand}

Figure 9. U.S. Petroleum Demand

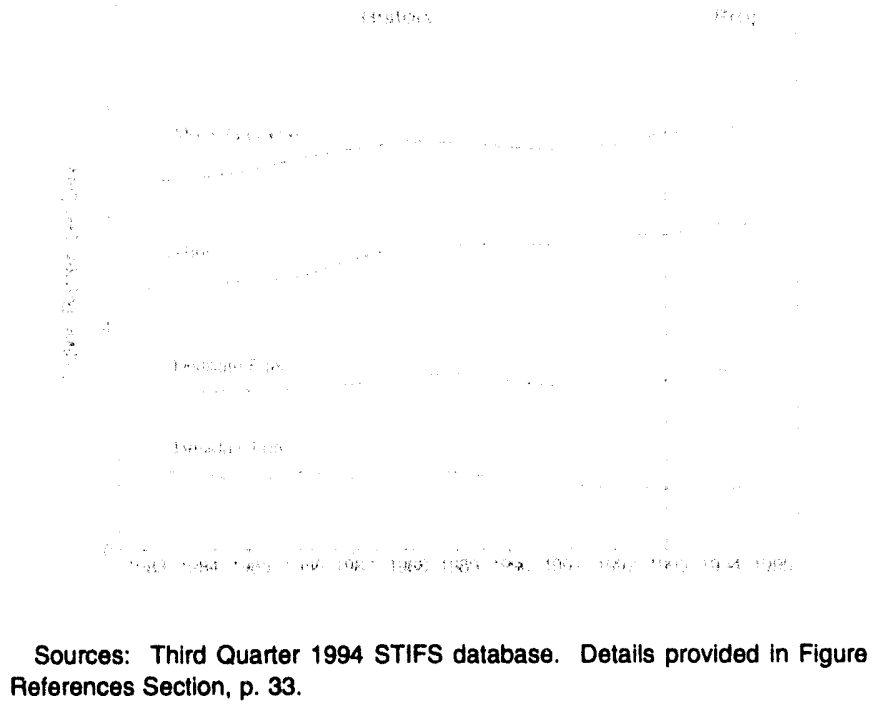

- Robust economic growth, declining oil prices and extreme weather during the first half of the year are expected to boost total petroleum demand in 1994 by nearly 500,000 barrels per day, or 2.8 percent (Figure 9 and Table 7). In 1995, slower economic growth, recovery in product prices and presumed normal weather are expected to slow demand growth to about 90,000 barrels per day, or 0.5 percent.

- Motor gasoline demand is projected to increase by an average 1.2 percent through 1995 . Despite accelerated economic growth and continued declines in real fuel costs per mile, travel is projected to increase by only 2.2 percent in 1994, partly as a result of the severe winter (Table 3). Assumptions of normal weather result in a 2.8-percent increase in 1995 despite a slowing economy. Efficiency is expected to increase at an average of 1.3 percent, reflecting lack of fuel economy growth in new vehicles and a decline in the retirement rate of older, less fuel-efficient ones (Figure 10 and Table 7).
Figure 10. Gasoline Market Indicators
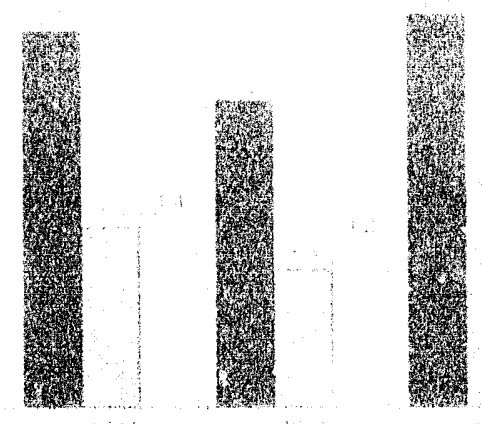

Sources: Third Quarter 1994 STIFS database. Details provided in Figure References Section, p. 33.

- Jet fuel demand is projected to increase at an average 1.8-percent rate through 1995 . This reflects the almost 6-percent increases in capacity and revenue ton-miles in 1994 (Table 3) due to strong economic growth and a 14percent decline in real ticket prices (Table 3 ).

- First-half 1994 distillate demand is estimated to have been 420,000 barrels per day higher than last year due mostly to weather effects. For the year as a whole, demand is projected to rise 5.3 percent. Assuming normal weather, growth of only 1.4 percent is expected in 1995.

- Residual fuel oil demand is projected to rise by 2 percent in 1994 due to the weatherrelated spike in the first quarter. Slower growth and firming prices are expected to result in no growth in 1995.

- Growth in petrochemicals as well as weatherrelated growth in asphalt and road-oil demand contribute to the 2.2 percent growth in other oils in 1994. Weather patterns account for most of the 1.8 percent growth in 1995. 
Sources: Thircl Quarter 1994 STIFS database and Energy Information Administration, Reserves and Natural Gas Division. Details provided in Figure References Section, p. 33.

- At mid-case prices, total U.S. domestic crude oil production is expected to decline by 170,000 barrels per day (2.4 percent) in 1994, and an additional 120,000 barrels per day (1.8 percent) in 1995 (Tables 1 and 7 and Figure 11).

- Crude production in the lower 48 States is expected to drop by 150,000 barrels per day in 1994, and by 70,000 barrels per day in 1995 (Table 7). Oil production from new projects in Federal offshore waters (the Santa Ynez unit in the Pacific, and the Augen project in the Gulf of Mexico) is expected to account for about 1 percent of total U.S. crude production by the end of 1994, if development goes as planned. ${ }^{5}$

- Crude production in Alaska is expected to decline slightly (0.7 percent) in 1994, and then 2.9 percent in 1995 (Table 7). The Point McIntyre Field started producing in late 1993 and is expected to produce about 100,000 barrels per day during the forecast period. In addition, the Niakuk Field is expected to come online in the third quarter of 1994 and produce about 15,000 barrels per day for the remainder of the forecast period. ${ }^{6}$
Sources: Third Quarter 1994 STIFS database. Details provided in Figure Peferences Section, p. 33.

- Crude oil production could be as high as 6.72 million barrels per day by the fourth quarter of 1995, given the high price case and production from new projects in the Federal Offshore, or as low as 6.07 million barrels per day under the low price scenario (Table 10).

- Declining oil production and rising demand in the United States means an increase in net imports of crude oil and products of 520 thousand barrels per day between 1993 and 1995. This would equal 45.7 percent of total petroleum demand in 1995 in the base case (Figure 12). The net import share of demand could range from 48.3 percent in the low price case to 44.3 percent in the high price case in 1995 (Tables 6 and 8).

- With increasing oil and gas prices, the rig counts for the remainder of 1994 are expected to follow a slight upward trend. This should result in an average of 774 rigs for 1994, followed by an increase in 1995 to 823. Although drilling has declined sharply since the early 1980's, the impact of the decline is partially offset by improvements in drilling technology and efficiency. 
Figure 14. Gross Refined Product Margins (Change from Year Ago)
Sources: Third Quarte: 1994 STIFS database. Details provided in Figure References Section, p. 33.

- The marked slide in crude oil prices that began in mid-1993 ended in the first quarter of 1994, with second quarter prices for imported crude oil recovering by more than $\$ 2.00$ per barrel from winter levels (Figure 13 and Table 5). Although sharp increases are not expected in the short term, a gradual climb in prices is projected, from the June 1994 average of $\$ 16.00$, to $\$ 18.00$ by the end of 1995 .

- Most major refined products were still being priced below year-ago levels during the first half of 1994, with the exception of diesel fuel, for which prices were equal, on average, to first-half 1993 levels, despite generally lower crude prices. Apparently, added costs associated with the new requirements for low sulfur content, combined with increased federal excise taxes, offset lower refining input costs. For first-half 1994, gross margins on diesel fuel (refiner price less crude oil cost per gallon) rose about 4 cents per gallon, or about 15 percent. $^{8}$

- Despite steady demand growth, gasoline markets did not exhibit the same relative strength as diesel fuel in the first half of 1994,
Sources: Third Quarter 1994 STIFS database. Details provided in Figure References Section, p. 33.

as 1994 retail gasoline prices were generally about a nickel below year-ago levels. Gasoline margins rose during this period, but only by about three cents per gallon. This increase fell short of even the federal excise tax increase instituted last October.

- Early indications are, however, that petroleum product markets have provided ample benefit in terms of net profit to U.S. refiners so far in 1994 (Figure 14). First quarter net income for U. S. refiners approximately doubled from 1993 levels, with majors reporting an increase of about 82 percent in refining/marketingrelated income, while independent refiners showed income increases of 115 percent for the same period. ${ }^{9}$

- Gradual increases in crude oil prices and products demand are expected to lift average U.S. product prices during the rest of 1994, and in 1995 . Unit profitability should slip somewhat from the relatively high levels of early 1994, assuming demand and supply for products remain in balance, if incremental supply costs associated with reformulated gasoline are not fully passed through in 1995. 
Sources: Third Quarter 1994 STIFS database. Details provided in Figure Peferences Section, p. 33.

- Natural gas spot prices were not as robust during the first half of 1994 as estimated in the second quarter 1994 Outlook. As a result, average wellhead gas prices for 1994 are expected to be up only six cents per thousand cubic feet ( 3 percent) compared to 1993, rather than the nineteen cents projected in the previous Outlook (Figure 15 and Table 5). Quite possibly this development reflects a less tight supply situation in the U.S. than previously expected, a finding discussed in some detail in a recent EIA report. ${ }^{10}$

- Relative price strength for gas remains a salient item in this Outlook, however. Despite the possibility of a second consecutive decline in average annual crude oil prices, gas prices (and demand) are expected to post steady gains. By 1995, in the base case scenario, wellhead gas prices are expected to be about 25 percent higher than in 1992, while electric utility prices for gas are seen rising to about 15 percent above 1992 levels. Meanwhile, crude prices are not expected to reach as high as 1992 levels next year, and utility prices for oil will probably be about flat relative to 1992 (Table 5 and Figure 15).
Sources: Third Quarter 1994 STIFS database. Detalls provided in Figure References Section, p. 33.

- Residential natural gas prices are projected to increase by 44 cents per thousand cubic feet (7.2 percent) from 1993 to 1995 , due to higher wellhead prices and the increased costs related to industry restructuring under FERC Order 636 (Table 5).

- A range of crude oil prices are deemed plausible for the current Outlook, deperiding upon world supply and demand conditions. Principally because of the uncertainty in crude oil prices, petroleum product prices are viewed as moving within ranges of about 5 to 10 cents per gallon above or below the mid price case, as indicated in Table 5.

- Similar uncertainty regarding natural gas wellhead prices pervades the forecast (Figure 16). These prices, while influenced by movements in oil prices to some extent, depend most heavily on the underlying strength in domestic gas markets. Severe weather conditions during winter, for example, can boost prices significantly in winter and through the spring and summer storage injection season, especially when non-heating demand remains strong throughout the year. 


\section{U.S. Oil Demand and Supply Sensitivities}

Figure 17. Total Petroleum Demand: Macro Cases
Figure 18. Total Petroleum Demand: Weather Cases
Sources: Third Quarter 1994 STIFS database. Details provided in Figure References Section, p. 33.

- The petroleum demand and supply outlook for the mid-price case is based on normal temperatures and a particular set of macroeconomic assumptions. To enhance the usefulness of the mid-case forecast, ranges of possible outcomes for petroleum demand and supply, using alternative macroeconomic, price, and weather assumptions, are also derived (Table 9). Plausible macroeconomic and weather-related petroleum demand cases are illustrated in Figures 17 and 18.

- The petroleum price sensitivity assumes that nonpetroleum prices remain constant. The weather sensitivities assume deviations above and below normal that correspond to one-half of the largest quarterly deviations from normal in heating and cooling degree-days over the last 15 years.

- A 1-percent increase in real GDP raises petroleum demand by about 135,000 barrels per day. Actual impacts from shifts in economic growth may vary depending upon the distribution of incremental growth across energy intensive and non-energy-intensive sectors.
Sources: Third Quarter 1994 STIFS database. Details provided in Figure Reierences Section, p. 33.

- A \$1-per-barrel increase in crude oil prices, assuming no price response from nonpetroleum energy sources, reduces demand by about 31,000 barrels per day.

- A \$1-per-barrel increase in crude oil prices boosts domestic oil supply (crude oil and natural gas liquids production) by 87,000 barrels per day.

- A 1-percent increase in heating degree-days increases demand by about 28,000 barrels per day. The impact of heating degree-days deviations from normal is not likely to be symmetrical. Because of new upward revisions in EIA's current estimates and projections for natural gas productive capacity, the weather sensitivity of oil demand in the Outlook has been significantly reduced. ${ }^{11}$

- A 1-percent increase in cooling degree-days increases petroleum demand by about 6,000 barrels per day.

(See Appendix A for sensitivity calculation methodology.) 
Figure 19. U.S. Natural Gas Demand Trends

Sources: Third Quarter 1994 STIF.S database. Details provided in Figure References Section, p. 33.

- Natural gas demand in 1994 is expected to grow across all sectors, more quickly than in 1993 (Figure 19). Strong economic growth and cold weather account for the rapid growth this year. As the economy slows somewhat, and as weather returns to normal, natural gas demand growth decelerates in 1995.

- In 1994, natural gas demand is expected to total 21.11 trillion cubic feet, reflecting a growth rate of 4.7 percent compared with 1993. In 1995, natural gas demand is projected to grow by 1.9 percent, to 21.53 trillion cubic feet (Table 11).

- Industrial demand for natural gas is growing fastest, and is forecast to increase by 5.4 percent in 1994 and by 4.3 percent in 1995 (Figure 20). This is due to rising manufacturing production, and expanding use of natural gas by non-utility generators. Also, environmental considerations mandated by the Clean Air Act are tending to favor natural gas use.

- Utility gas demand is expected to continue to rise throughout the forecast period due to increasing electricity demand. Environmental
Figure 20. U.S. Natural Gas Demand by Sector

Sources: Third Quarter 1994 STIFS databaso. Details provided in Figure Relerences Section, p. 33.

regulations and taxes on petroleum have increased the price level at which fuel switching from gas to oil is profitable. ${ }^{12}$ In 1994, utility gas demand is expected to rise by 7.8 percent, and by an additional 3.1 percent in 1995.

- Residential sector demand in 1994 is expected to be up by 3.8 percent. This increased demand primarily reflects the continued addition of new natural gas customers, but also the severe winter weather experienced in the first quarter of 1994 . Under the assumption of normal weather in 1995, residential demand is projected at less than 1994 levels.

- Despite strong natural gas demand growth, weak oil prices early this year and an improved outlook for gas capacity have resulted in only modest increases in gas wellhead prices. In 1995, as gas demand continues to grow and as oil prices increase, the gas wellhead price is expected to increase by 5.2 percent (Table 5 ). 


\section{U.S. Natural Gas Supply}

Figure 21. U.S. Dry Gas Production and Net Imports
Figure 22. Total Gas in Underground Storage
Sources: Third Quarter 1994 STIFS database and Energy Information Administration, Reserves and Natural Gas Division. Details provided in Figure References Section, p. 33.

- U.S. dry gas production continues to rise steadily, although not as fast as demand. In 1994, dry gas production is forecast to increase by 2.2 percent compared with 1993, and a further 3.3 percent in 1995 (Figure 21 and Table 11).

- From 1986 to 1993, the large U.S. surplus wellhead productive capacity has been declining sharply as demand for gas rose, gas prices fell and gas well completions dropped. This declining trend is expected to be reversed in 1994 and 1995 if natural gas prices and drilling meet or exceed the base case assumptions. ${ }^{13}$

- Because of the significant improvement in gas prices since the lows of February 1992, gas drilling has been rising, particularly since February 1994. The estimated number of gas wells drilled in June 1994 was 408, which was 25 percent higher than in June 1993. ${ }^{14}$
Sources: Third Quarter 1994 STIFS database. Details provided In Figure References Section, p. 33.

- Net natural gas imports growth is forecast at 13.9 percent in 1994, and 3.3 percent in 1995, compared to 11.1 percent in 1993. The high growth of imports in 1994 is due mainly to the January 1994 cold snap. A slowing of the rate of imports growth is inevitable as Canada approaches its export ceiling of 3 trillion cubic feet per year, as estimated in a study for the Canadian National Energy Board. ${ }^{15}$

- Increasing linkage between Canadian gas prices and U.S. spot prices, and expanding pipeline capacity stand to further the integration of the U.S.-Canadian gas market.

- Natural gas storage levels have been rising strongly in May and June after ending the heating season at below average levels. Working gas storage was estimated at over 50 percent full in mid-June. Lower spot prices relative to year ago have encouraged the strong start to the injection season (Figure 22). 
Sources: Third Quarter 1994 STIFS database. Detalls provlded in Figure References Section, p. 33.

- Total domestic coal consumption grew by an estimated 3.7 percent in 1993. In 1994, an increase of 1.9 percent is forecast (Table 12). Growth in electricity demand will be the main impetus to growth in coal demand (Figure 21). Coal consumption in 1995 is expected to grow by 1.4 percent.

- Utility coal demand is expected to increase by 2.2 percent in 1994, and 1.6 percent in 1995 (Table 12). Coal represents 50 percent of inputs to electricity generation.

- Demand for coal at coke plants is expected to decline in 1994, due to stock withdrawals and imports of coal, and grows by only 1.6 percent in 1995, despite increased raw steel production. Imports of coal coke, production of steel by electric arc furnaces, and capacity limits at domestic coking plants are expected to constrain future domestic coal demand growth in steel production.
Sources: Third Quarter 1994 STIFS database and Energy Information Administration, Office of Coal, Nuclear, Electric, and Altemative Fuels. Details provided in Figure References Section, p. 33.

- Coal demand by the retail and general industry sectors will grow by 1.3 percent in 1994. Severe weather in the first quarter led to sharp increases in the consumption of coal by the industrial, residential and commercial sectors. Consumption demand growth in 1995 is expected to be flat relative to 1994 . Demand from these sectors begins to shrink as coal is displaced to meet environmental regulations and conservation initiatives.

- U.S. coal exports are not expected to experience significant growth until 1995. Exports decline by 11.8 percent in 1994 . In 1995, export growth recovers along with the global economy, increasing by 9.6 million short tons, or 14.6 percent (Table 12).

- Coal production is expected to grow by 8.4 percent in 1994, as stocks are replenished, and coal consumption increases (Figure 22). 


\section{U.S. Electricity Demand and Supply}

Figure 25. Electricity Demand Changes by Sector

Sources: Third Quarter 1994 STIFS database. Details provided in Figure References Section, p. 33.

- The exceptionally strong growth in residential electricity demand seen in 1993 is not expected to be repeated this year (Figure 25). Nevertheless, 1994 has already yielded residential demand strength due to the cold winter and hot June. With other sectors exhibiting steady growth this year, total demand for electricity should increase by about 3.3 percent, assuming normal weather for the rest of the year (Table 13).

- Total electricity demand growth in 1995 is likely to fall to 2 percent if weather returns to normal. This slowing down in electricity growth next year is reinforced by a slower rate of economic growth.

- Industrial electricity demand growth in both 1994 and 1995 is expected to rise by 1.7 percent annually, reflecting the increase in manufacturing production (Figure 25 and Table 13).

- Coal, oil and natural gas-fired generation are expected to experience the greatest expansion in 1994, while hydropower decreases. Lower prices for oil and gas prompt rising utility use
Figure 26. U.S. Electricity Jupply Trends

Sources: Third Quarter 1994 STIFS database and Energy Information Administration, Office of Coal, Nuclear, Electric and Alternate Fuels. Details provided in Figure References Section, p. 33.

of these fuels, while below normal water conditions and environmental concerns in the west restrict hydropower (Figure 26).

- Net imports of electricity from Canada are expected to be high in 1994, mainly from Ontario Hydro and Hydro Quebec. This is due mainly to increased interruptible purchases as both utilities have large amounts of excess capacity. Imports are expected to drop back toward normal levels in 1995, as some of the excess Canadian capacity is needed to meet increased domestic demand in some of the provinces. ${ }^{16}$

- In 1994 nuclear generation is expected to grow by 1.9 percent because of projected increases in capacity and utilization. In 1995, Watts Bar 1, located in Spring City, Tennessee, is expected to receive its full-power license.

- U.S. utilities are expected to generate about 2.0 and 1.6 percent more electricity in 1994 and 1995, respectively. Non utility generation is expected to increase at even faster rates of 9.0 percent in 1994, and 8.3 percent in 1995, following a trend beginning in 1984. 
Table 2. U.S. Macroeconomic and Weather Assumptions

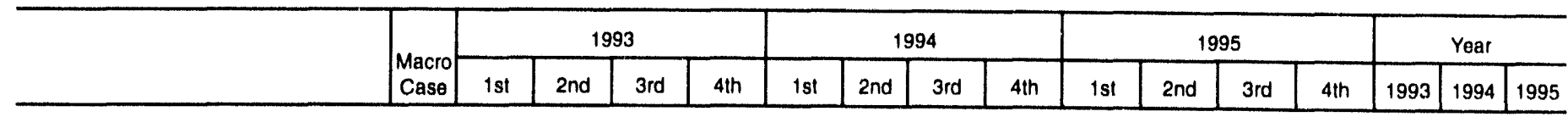

Macroeconomic *

Real Gross Domestic Product

(billion 1987 dollars) . . . . . . . . MId

Low

Percentage Change from Prior Year ... Mid

Low

Annualized Percent Change

Pror Quarter ............. Mid

GDP Implicit Price Deflator

(Index, 1987=1.000) $\ldots \ldots \ldots \ldots$ High

Low

Percentage Change from Pilor Year ... Mid

Real Disposable Personal Income High

(billlon 1987 Dollars) ... . . . . . . . . Mid

Low

Percentage Change from Prior Year ... Mid

Manufacturing Production

(Index, 1987=1.000)

High

Miy

Low

Percentage Change from Prior Year ... Mid

OECD Economic Growth (percent) ${ }^{b} \ldots$

Weather ${ }^{\circ}$

Heating Degree-Days

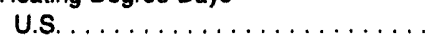

Middle Atlantic $\ldots \ldots \ldots \ldots \ldots \ldots \ldots \ldots \ldots \ldots$

U.S. Gas-Weighted . . . . . . . .

Cooling Degree-Days (U.S.) . . . . . . $\begin{array}{lllllll}5078 & 5102 \quad 5130 & 5220 & 532 & 5419 & 547\end{array}$

$5350 \quad 5376 \quad 5400$

3.22

$\begin{array}{llllllll}1.233 & 1.240 & 1.245 & 1.249 & 1.257 & 1.266 & 1.275\end{array}$

2.8

36433694

$694 \quad 3709$

$1.8 \quad 2$.

2.4

1.1031 .112

2.7

2.2

$1.9 \quad 2$

2.4
2.4
2.5

$\begin{array}{ll}2.6 & 2.5 \\ 2.8 & 2.9\end{array}$

2.8
3.0

$\begin{array}{lll}3904 & 3947 & 3992\end{array}$

38713890

$3839 \quad 3833$

3911
3830

$\begin{array}{lll}3.9 & 4.3 & 4.7\end{array}$

$\begin{array}{lll}3.9 & 4.3 & 4.7 \\ 3.0 & 2.8 & 2.6 \\ 2.1 & 1.3 & 0.5\end{array}$

2.

4.13 .0

$0.1 \quad 0.2$

$\begin{array}{ll}1.275 & 1.278\end{array}$

$1.217 \quad 1.220$

$1.160 \quad 1.162$

62

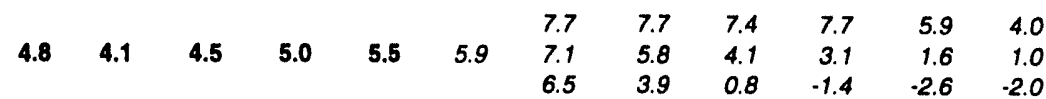

\begin{tabular}{|c|c|c|c|c|c|c|c|c|c|c|c|c|c|c|}
\hline $\begin{array}{l}2351 \\
313\end{array}$ & 534 & 109 & 1682 & 2364 & 496 & 89 & 1636 & 2327 & 524 & 89 & 1636 & 4676 & 4584 & 4576 \\
\hline 3413 & & 148 & 2303 & 3512 & 869 & 171 & 2269 & 3267 & 915 & 171 & 2269 & 6709 & 6821 & 6621 \\
\hline 3049 & 677 & 105 & 2078 & 3258 & 654 & 105 & 2026 & 2993 & 716 & 105 & 2026 & 5909 & 6044 & 5839 \\
\hline 2367 & 539 & 115 & 1733 & 2496 & 525 & 81 & 1686 & 2426 & 539 & 81 & 1686 & 4754 & 4788 & 4732 \\
\hline 29 & 317 & 810 & 61 & 25 & 373 & 758 & 72 & 30 & 334 & 758 & 72 & 1217 & 1227 & 1193 \\
\hline
\end{tabular}

- Macroeconomic projections from DAIMcGraw-Hill model forecasts are seasonally adjusted at annual rates and modified as appropriate to the mid world oil price case. These mid-case macroeconomic projections are then modified by the low and high world oil price cases (as shown in Table 5 ) and by various explicit economic assumptions, with the low world oll price case applied to the high macroeconomic case, and the high world oil price case applled to the low macroeconomic case.

'OECD: Organization for Economic Cooperation and Development.

' Population-weighted degree days. A degree day indicates the temperature variation from 65 degrees Fahrenteit (calculated as the simple average of the daily minimum and maximum temperatures) weighted by 1980 population. Normal is used for the forecast period and is defined as the average number of degree days between 1951 and 1980 for a given period.

Note: Historical data are printed in bold, forecasts are in italic

Sources: Historical data: Energy Information Administration, Monthly Energy Review, DOE/EIA-0035(943/0612); U.S. Department of Commerce, Bureau of Economic Analysis, Survey of Current Business, May 1994; U.S. Department of Commerce, National Oceanic and Atmospheric Administration, Monthly State, Regional, and National Heating/Cooling Degree Days Weighted by Population, Federal Reserve System, Statistical Release G.17(419), May 1994. Macroeconomic projections are based on DRI/McGraw-Hill Forecast CONTROL0694. 
Table 3. U.S. Energy Indicators: Mild World Oil Price Case

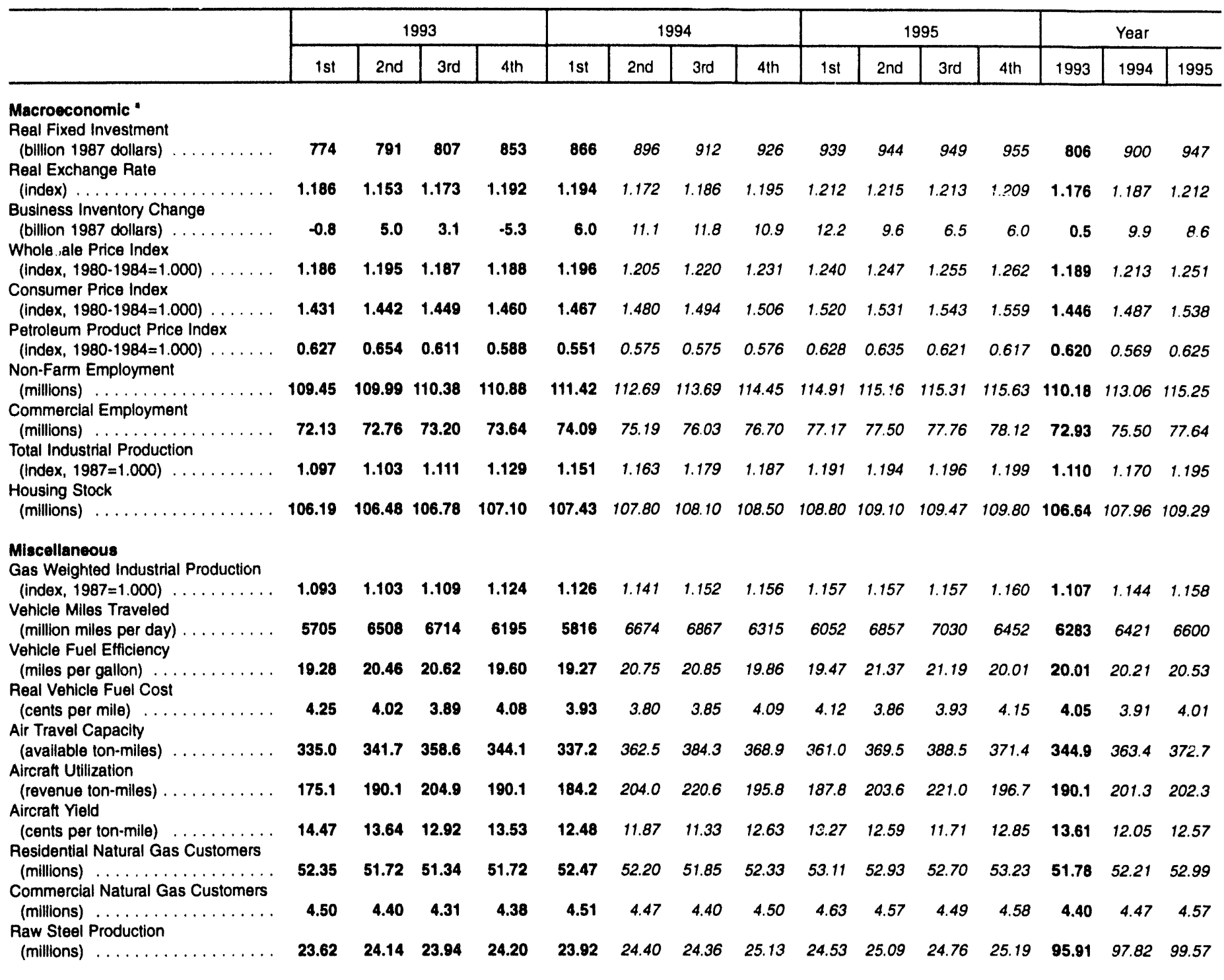

- Macroeconomic projections from DRIMcGraw-Hill model forecasts are seasonally adjusted at annual rates and modified as appropriate to the mid world oil price case. These mid-case inacroeconomic projections are then modified by the low and high world price cases (as shown in Table 5) and by various explicit economic assumptions, with low world oll price case applied to the high macroeconomic case, and high world oil price case applied to the low macroeconomic case.

Note: Historical data are printed in bold, forecasts are in italic.

Sources: Historical data: Energy Information Administration, Monthly Energy Review, DOE/EIA-0035(94/06); U.S. Department of Commerce, Bureau of Economic Analysis, Survey of Current Business, May 1994; U.S. Department of Commerce, National Oceanlc and Atmospheric Administration, Monthly State, Regional, and National Heating/Cooling Degree Days Weighted by Population, Federal Resenve System, Statistical Release G.17(419), May 1994. Macroeconomic projections are based on DRI/McGraw-HIII Forecast CONTROL0694. 
Table 4. International Petroleum Supply and Demand: Mid World Oil Price Case (Million Barrels per Day, Except Closing Stocks)

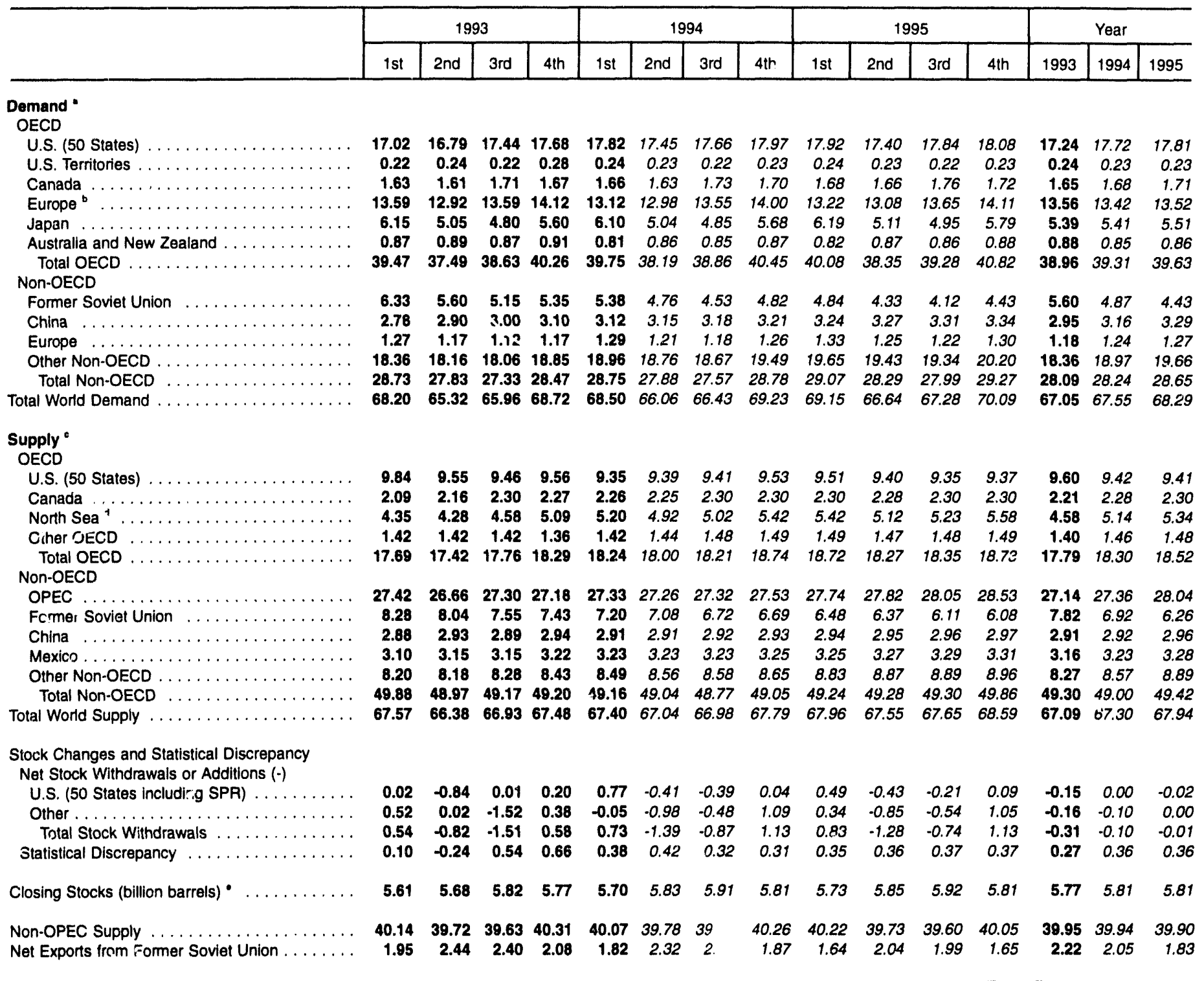

- Derriand for petroleum by the OECD countries is synonymous with "petroleum product supplied" which is defined in the glossary of the EIA Petroleum Supply Monthly, DOE/EIA-0109. Demand for petroleum by the non-OECD countries is "apparent consumption" which includes internal consumption, refinery fuel and loss, and bunkering.

' OECD Europe includes eastern Germany.

'Includes production of crude oil (including lease condensates), natural gas plant liquids, other hydrogen and hydrocarbons for refinery feedstocks, refinery gains, alcohol, and liquids produced from coal and other sources.

Includes offshore supply from Drilmark, Germany, the Netherlands, Norway, and the United Kingdom.

- Excludes stocks held in the Former CPEs.

OECD: Organization for Economic Cooperation and Development

OPEC: Organization of Petroleum Exporting Countries

SPR: Strategic Petroleum Reserve

Former CPEs: Albania, Bulgaria, Cambodia, China, Cuba, the Czech and Slovak Federal Republic, Hungary, Laos, Mongolia, North Korea, Poland, Romania, the Former Soviet Union, Vietnam, and Former Yugoslavia

Notes: Minor discrepancies 'with other publishecl ElA historical data are due to rounding. Historical data are printed in bold, forecasts are in itallc. The forecasts were generated by simulation of the Short-Term Integrater Forecasting System.

Sources: Energy Information Administration, Intemational Petroleum Statistics Repont, DOE/EIA-0520(94/03); and Intemational Energy Annual 1992, DOE/EIA-0219(92): Organization for Economic Cooperation and Development, Annual and Monthly Oil Statistics Database through May 1994. 
Table 5. U.S. Energy Prices

(Nominal Dollars)

\begin{tabular}{|c|c|c|c|c|c|c|c|c|c|c|c|c|c|c|c|c|}
\hline & \multirow{2}{*}{$\begin{array}{l}\text { Price } \\
\text { Case }\end{array}$} & \multicolumn{4}{|c|}{1993} & \multicolumn{4}{|c|}{1994} & \multicolumn{4}{|c|}{1995} & \multicolumn{3}{|c|}{ Year } \\
\hline & & $1 \mathrm{st}$ & 2nd & 3rd & 4 th & $1 \mathrm{st}$ & 2nd & 3rd & 4 th & 1st & 2nd & 3rd & 4th & 1993 & 1994 & 1995 \\
\hline Imported Crude Oll • & Low & & & & & & & 12.00 & 13.00 & 13.00 & 13.00 & 13.00 & 13.00 & & 13.33 & 13.00 \\
\hline (doilars per barrel) $\ldots \ldots \ldots \ldots \ldots$ & $\begin{array}{l}\text { Mid } \\
\text { High }\end{array}$ & 17.34 & 17.67 & 15.60 & 14.09 & 13.01 & 15.39 & $\begin{array}{l}16.00 \\
18.00\end{array}$ & $\begin{array}{l}16.50 \\
19.00\end{array}$ & $\begin{array}{l}16.50 \\
19.00\end{array}$ & $\begin{array}{l}17.00 \\
19.50\end{array}$ & $\begin{array}{l}17.50 \\
20.00\end{array}$ & $\begin{array}{l}18.00 \\
21.00\end{array}$ & 16.13 & $\begin{array}{l}15.32 \\
16.48\end{array}$ & $\begin{array}{l}17.28 \\
19.91\end{array}$ \\
\hline $\begin{array}{l}\text { Natural Gas Wellhead } \\
\text { (dollars per thousand cubic feet) }\end{array}$ & $\begin{array}{l}\text { Low } \\
\text { Mid } \\
\text { High }\end{array}$ & 1.88 & 2.09 & 2.03 & 2.02 & 2.00 & 1.86 & $\begin{array}{l}1.93 \\
2.11 \\
2.16\end{array}$ & $\begin{array}{l}2.11 \\
2.30 \\
2.54\end{array}$ & $\begin{array}{l}2.04 \\
2.28 \\
2.52\end{array}$ & $\begin{array}{l}1.84 \\
2.02 \\
2.16\end{array}$ & $\begin{array}{l}1.86 \\
2.11 \\
2.25\end{array}$ & $\begin{array}{l}2.11 \\
2.30 \\
2.53\end{array}$ & 2.01 & $\begin{array}{l}1.98 \\
2.07 \\
2.15\end{array}$ & $\begin{array}{l}1.96 \\
2.18 \\
2.37\end{array}$ \\
\hline \multicolumn{17}{|l|}{ Petroleum Products } \\
\hline Gasoline Retail $^{b}$ & Low & & & & & & & 1.12 & 1.14 & 1.14 & 1.17 & 1.18 & 1.18 & & 1.13 & 1.17 \\
\hline (dollars per gallon) $\ldots \ldots \ldots \ldots \ldots \ldots$ & $\begin{array}{l}\text { Mid } \\
\text { High }\end{array}$ & 1.17 & 1.19 & 1.16 & 1.17 & 1.11 & 1.15 & $\begin{array}{l}1.20 \\
1.24\end{array}$ & $\begin{array}{l}1.22 \\
1.28\end{array}$ & $\begin{array}{l}1.22 \\
1.28\end{array}$ & $\begin{array}{l}1.26 \\
1.32\end{array}$ & $\begin{array}{l}1.29 \\
1.34\end{array}$ & $\begin{array}{l}1.29 \\
1.36\end{array}$ & 1.17 & $\begin{array}{l}1.17 \\
1.20\end{array}$ & $\begin{array}{l}1.26 \\
1.33\end{array}$ \\
\hline No. 2 Diesel Oil, Retail & Low & & & & & & & 1.05 & 1.13 & 1.12 & 1.11 & 1.12 & 1.16 & & 1.10 & 1.13 \\
\hline (dollars per gallon) $\ldots \ldots \ldots \ldots \ldots \ldots$ & $\begin{array}{l}\text { Mid } \\
\text { High }\end{array}$ & 1.10 & 1.10 & 1.08 & 1.19 & 1.10 & 1.11 & $\begin{array}{l}1.15 \\
1.19\end{array}$ & $\begin{array}{l}1.21 \\
1.27\end{array}$ & $\begin{array}{l}1.20 \\
1.26\end{array}$ & $\begin{array}{l}1.21 \\
1.27\end{array}$ & $\begin{array}{l}1.22 \\
1.28\end{array}$ & $\begin{array}{l}1.28 \\
1.35\end{array}$ & 1.12 & $\begin{array}{l}1.14 \\
1.17\end{array}$ & $\begin{array}{l}1.23 \\
1.29\end{array}$ \\
\hline No. 2 Heating Oil, Wholesale & Low & & & & & & & 0.41 & 0.47 & 0.46 & 0.44 & 0.44 & 0.48 & & 0.48 & 0.46 \\
\hline (dollars per gallon) $\ldots \ldots \ldots \ldots \ldots$ & $\begin{array}{l}\text { Mid } \\
\text { High }\end{array}$ & 0.57 & 0.56 & 0.52 & 0.51 & 0.53 & 0.52 & $\begin{array}{l}0.51 \\
0.56\end{array}$ & $\begin{array}{l}0.56 \\
0.62\end{array}$ & $\begin{array}{l}0.54 \\
0.61\end{array}$ & $\begin{array}{l}0.54 \\
0.60\end{array}$ & $\begin{array}{l}0.56 \\
0.62\end{array}$ & $\begin{array}{l}0.61 \\
0.68\end{array}$ & 0.55 & $\begin{array}{l}0.53 \\
0.56\end{array}$ & $\begin{array}{l}0.56 \\
0.63\end{array}$ \\
\hline $\begin{array}{l}\text { No. } 2 \text { Heating Oil, Retail } \\
\text { (dollars per gallon) } \ldots \ldots\end{array}$ & $\begin{array}{l}\text { Low } \\
\text { Mid } \\
\text { High }\end{array}$ & 0.95 & 0.91 & 0.85 & 0.88 & 0.90 & 0.86 & $\begin{array}{l}0.75 \\
0.84 \\
0.88\end{array}$ & $\begin{array}{l}0.84 \\
0.92 \\
0.98\end{array}$ & $\begin{array}{l}0.87 \\
0.96 \\
1.02\end{array}$ & $\begin{array}{l}0.83 \\
0.93 \\
0.99\end{array}$ & $\begin{array}{l}0.80 \\
0.91 \\
0.97\end{array}$ & $\begin{array}{l}0.86 \\
0.98 \\
1.05\end{array}$ & 0.91 & $\begin{array}{l}0.86 \\
0.90 \\
0.92\end{array}$ & $\begin{array}{l}0.85 \\
0.95 \\
1.02\end{array}$ \\
\hline $\begin{array}{l}\text { No. } 6 \text { Residual Fuel Oil, Retail }{ }^{c} \\
\text { (dollars per barrel) } \ldots \ldots \ldots \ldots\end{array}$ & $\begin{array}{l}\text { Low } \\
\text { Mid } \\
\text { High }\end{array}$ & 14.72 & 15.13 & 13.52 & 12.71 & 14.25 & 13.24 & $\begin{array}{r}9.89 \\
12.80 \\
14.26\end{array}$ & $\begin{array}{l}11.47 \\
14.02 \\
15.85\end{array}$ & $\begin{array}{l}12.00 \\
14.55 \\
16.39\end{array}$ & $\begin{array}{l}11.48 \\
14.38 \\
16.20\end{array}$ & $\begin{array}{l}11.50 \\
14.75 \\
16.56\end{array}$ & $\begin{array}{l}12.36 \\
15.89 \\
18.08\end{array}$ & 13.97 & $\begin{array}{l}12.29 \\
13.63 \\
14.43\end{array}$ & $\begin{array}{l}11.86 \\
14.90 \\
16.82\end{array}$ \\
\hline \multicolumn{17}{|l|}{ Electric Utility Fuels } \\
\hline $\begin{array}{l}\text { Coal } \\
\text { (dollars per million Btu). }\end{array}$ & $\begin{array}{l}\text { Low } \\
\text { Mid } \\
\text { High }\end{array}$ & 1.38 & 1.39 & 1.38 & 1.38 & 1.36 & 1.38 & $\begin{array}{l}1.37 \\
1.39 \\
1.42\end{array}$ & $\begin{array}{l}1.37 \\
1.39 \\
1.43\end{array}$ & $\begin{array}{l}1.37 \\
1.40 \\
1.44\end{array}$ & $\begin{array}{l}1.39 \\
1.42 \\
1.47\end{array}$ & $\begin{array}{l}1.36 \\
1.41 \\
1.46\end{array}$ & $\begin{array}{l}1.37 \\
1.41 \\
1.47\end{array}$ & 1.38 & $\begin{array}{l}1.37 \\
1.38 \\
1.40\end{array}$ & $\begin{array}{l}1.37 \\
1.41 \\
1.46\end{array}$ \\
\hline $\begin{array}{l}\text { Heavy Fuel Oil } \\
\text { (dollars per million Btu) }\end{array}$ & $\begin{array}{l}\text { Low } \\
\text { Mid } \\
\text { High }\end{array}$ & 2.50 & 2.60 & 2.30 & 2.14 & 2.40 & 2.25 & $\begin{array}{l}1.78 \\
2.25 \\
2.48\end{array}$ & $\begin{array}{l}2.09 \\
2.50 \\
2.80\end{array}$ & $\begin{array}{l}2.07 \\
2.47 \\
2.76\end{array}$ & $\begin{array}{l}1.97 \\
2.42 \\
2.71\end{array}$ & $\begin{array}{l}2.04 \\
2.56 \\
2.85\end{array}$ & $\begin{array}{l}2.23 \\
2.81 \\
3.16\end{array}$ & 2.36 & $\begin{array}{l}2.13 \\
2.35 \\
2.47\end{array}$ & $\begin{array}{l}2.08 \\
2.56 \\
2.86\end{array}$ \\
\hline $\begin{array}{l}\text { Natural Gas } \\
\text { (dollars per million Btu) }\end{array}$ & $\begin{array}{l}\text { Low } \\
\text { Mid } \\
\text { High }\end{array}$ & 2.58 & 2.63 & 2.52 & 2.54 & 2.64 & 2.41 & $\begin{array}{l}2.41 \\
2.57 \\
2.63\end{array}$ & $\begin{array}{l}2.63 \\
2.82 \\
3.03\end{array}$ & $\begin{array}{l}2.63 \\
2.87 \\
3.10\end{array}$ & $\begin{array}{l}2.34 \\
2.53 \\
2.68\end{array}$ & $\begin{array}{l}2.35 \\
2.59 \\
2.73\end{array}$ & $\begin{array}{l}2.61 \\
2.82 \\
3.03\end{array}$ & 2.56 & $\begin{array}{l}2.50 \\
2.60 \\
2.67\end{array}$ & $\begin{array}{l}2.46 \\
2.68 \\
2.85\end{array}$ \\
\hline \multicolumn{17}{|l|}{ Other Residential } \\
\hline $\begin{array}{l}\text { Natural Gas } \\
\text { (dollars per thousand cubic feet) }\end{array}$ & $\begin{array}{l}\text { Low } \\
\text { Mid } \\
\text { High }\end{array}$ & 5.70 & 6.46 & 7.88 & 6.22 & 6.04 & 6.66 & $\begin{array}{l}7.69 \\
7.84 \\
7.93\end{array}$ & $\begin{array}{l}6.14 \\
6.35 \\
6.48\end{array}$ & $\begin{array}{l}5.99 \\
6.19 \\
6.38\end{array}$ & $\begin{array}{l}6.64 \\
6.89 \\
7.12\end{array}$ & $\begin{array}{l}7.88 \\
8.18 \\
8.41\end{array}$ & $\begin{array}{l}6.29 \\
6.53 \\
6.72\end{array}$ & 6.15 & $\begin{array}{l}6.32 \\
6.39 \\
6.43\end{array}$ & $\begin{array}{l}6.36 \\
6.59 \\
6.79\end{array}$ \\
\hline $\begin{array}{l}\text { Electricity } \\
\text { (cents per kilowatthour) } \ldots \ldots \ldots\end{array}$ & $\begin{array}{l}\text { Low } \\
\text { Mid } \\
\text { High }\end{array}$ & 7.8 & 8.5 & 8.7 & 8.3 & 7.9 & 8.5 & $\begin{array}{l}8.7 \\
8.9 \\
9.2\end{array}$ & $\begin{array}{l}8.2 \\
8.5 \\
8.8\end{array}$ & $\begin{array}{l}7.9 \\
8.2 \\
8.8\end{array}$ & $\begin{array}{l}8.5 \\
8.8 \\
9.4\end{array}$ & $\begin{array}{l}8.8 \\
9.1 \\
9.7\end{array}$ & $\begin{array}{l}8.3 \\
8.6 \\
9.2\end{array}$ & 8.3 & $\begin{array}{l}8.3 \\
8.4 \\
8.7\end{array}$ & $\begin{array}{l}8.4 \\
8.7 \\
9.3\end{array}$ \\
\hline
\end{tabular}

- Cost of imported crude oll to U.S.

- Average for all grades and services.

Average for all sulfur contents.

Includes fuel oils No. 4, No. 5, and No. 6 and topped crude fuel oll prices.

Notes: Data are estimated for the second quarter of 1994. Prices exclude taxes, except prices for gasoline, residential natural gas, and diesel. Price cases are derived by simulating all energy produci price models under the assumptions of the three world oil price cases using the mid macroeconomic case and normal weather assumptions for all simulations. The forecasts were generated by simulation of the Short-Term Integrated Forecasting System.

Sources: Historical data: Energy Information Administration, Monthly Energy Review, DOE/EIA-0035(94/06); and Petroleum Marketing Monthly, DOEJEIA-03BO(94/06). 
Table 6. U.S. Petroleum Supply and Demand: Low World Oil Price Case

(Million Barrels per Day, Except Closing Stocks)

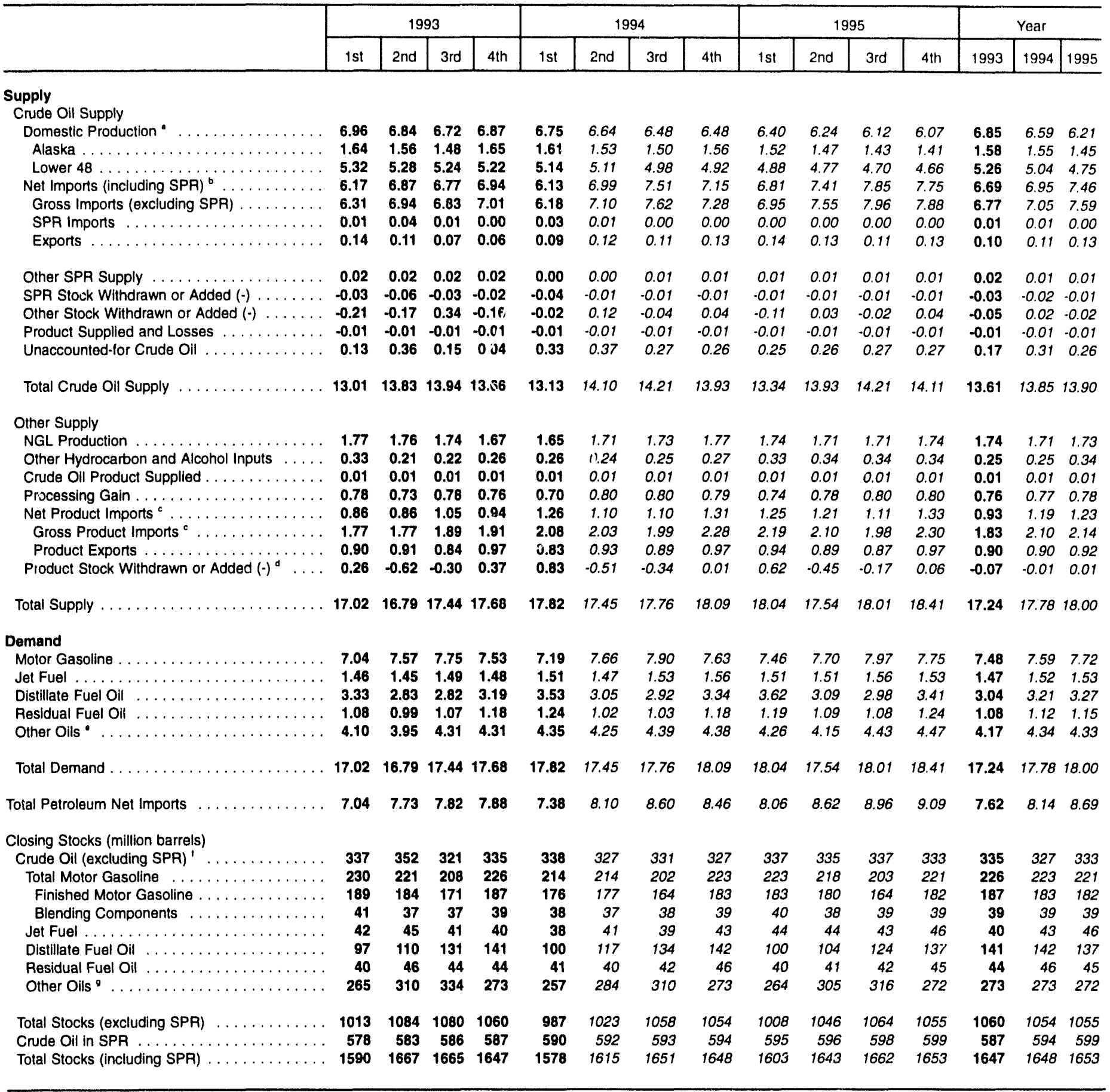

- Includes lease condensate.

- Net imports equals gross imports plus SPR imports minus exports.

- Includes finished petroleum products, unfinished oils, gasoline blending components, and natural gas plant liquids for processing.

Includes an estimate of minor product stock change based on monthly data.

- Includes crude oll product supplied, natural gas liquids, liquefied refinery gas, other liquids, and all finished petroleum products except motor gasoline, jet fuel, distillate, and residual fuel oil.

'Includes crude oil in transit to refineries.

- Includes stocks of all other oils such as aviation gasoline, kerosene, natural gas liquids (including ethane), aviation gasoline blending components, naphtha and other oils for petrochemical feedstock use, special naphthas, lube oils, wax, coke, asphalt, road oil, and miscellaneous oils.

SPR: Strategic Petroleum Reserve

NGL: Natural Gas Liquids

Notes: Minor discrepancies with other ElA published historical data are due to rounding. Historical data are printed in bold, forecasts are in italic. The forecasts were generated by simulation of the Short-Term Integrated Forecasting System.

Sources: Historical data: Energy Information Administration, Petroleum Supply Monthiy, DOE/EIA-0109(93/01-94/06); and Weekly, Petroleum Status Report, DOE/EIA-0208(various issues). 
Table 7. U.S. Petroleum Supply and Demand: Mid World Oil Price Case (Million Barrels per Day, Except Closing Stocks)

\begin{tabular}{|c|c|c|c|c|c|c|c|c|c|c|c|c|c|c|c|}
\hline & \multicolumn{4}{|c|}{1993} & \multicolumn{4}{|c|}{1994} & \multicolumn{4}{|c|}{1995} & \multicolumn{3}{|c|}{ Year } \\
\hline & 1st & 2nd & 3rd & 4th & 1st & 2nd & $3 r d$ & 4th & 1st & 2nd & 3 rd & 4th & 1993 & 1994 & 1995 \\
\hline \multicolumn{16}{|l|}{ Supply } \\
\hline Domestic Production " & 6.96 & 6.84 & 6.72 & 6.87 & 6.75 & 6.64 & 6.63 & 6.71 & 6.70 & 6.57 & 6.50 & 6.48 & 6.85 & 6.68 & 6.56 \\
\hline Alaska . & 1.64 & 1.56 & 1.48 & 1.65 & 1.61 & 1.53 & 1.54 & 1.60 & 1.59 & 1.54 & 1.50 & 1.48 & 1.58 & 1.57 & 1.53 \\
\hline Lower $48 \ldots$ & 5.32 & 5.28 & 5.24 & 5.22 & 5.14 & 5.11 & 5.09 & 5.11 & 5.10 & 5.03 & 5.00 & 5.01 & 5.26 & 5.11 & 5.04 \\
\hline Net Imports (including SPR) ${ }^{b}$. & 6.17 & 6.87 & 6.77 & 6.94 & 6.13 & 6.99 & 7.36 & 6.85 & 6.44 & 7.03 & 7.47 & 7.19 & 6.69 & 6.84 & 7.04 \\
\hline Gross Imports (excluding SPR) & 6.31 & 6.94 & 6.83 & 7.01 & 6.18 & 7.10 & 7.47 & 6.98 & 6.59 & 7.16 & 7.58 & 7.32 & 6.77 & 6.94 & 7.16 \\
\hline SPR Imports $\ldots \ldots \ldots \ldots$ & 0.01 & 0.04 & 0.01 & 0.00 & 0.03 & 0.01 & 0.00 & 0.00 & 0.00 & 0.00 & 0.00 & 0.00 & 0.01 & 0.01 & 0.00 \\
\hline Exports & 0.14 & 0.11 & 0.07 & 0.06 & 0.09 & 0.12 & 0.11 & 0.13 & 0.14 & 0.13 & 0.11 & 0.13 & 0.10 & 0.11 & 0.13 \\
\hline Other SPR Supply & 0.02 & 0.02 & 0.02 & 0.02 & 0.00 & 0.00 & 0.01 & 0.01 & 0.01 & 0.01 & 0.01 & 0.01 & 0.02 & 0.01 & 0.01 \\
\hline SPR & -0.03 & -0.06 & -0.03 & -0.02 & -0.04 & -0.01 & -0.01 & -0.01 & .0 .01 & .0 .01 & .0 .01 & .0 .01 & -0.03 & -0.02 & -0.01 \\
\hline Othe & -0.21 & -0.17 & 0.34 & -0.16 & -0.02 & 0.12 & -0.04 & 0.04 & -0.11 & 0.03 & -0.02 & 0.04 & -0.05 & 0.02 & -0.02 \\
\hline Product Supplied and Losses & -0.01 & -0.01 & -0.01 & -0.01 & -0.01 & -0.01 & -0.01 & .0 .01 & .0 .01 & -0.01 & -0.01 & -0.01 & -0.01 & -0.01 & .0 .01 \\
\hline Unaccounted-for Crude Oll & 0.13 & 0.36 & 0.15 & 0.04 & 0.33 & 0.37 & 0.27 & 0.26 & 0.25 & 0.26 & 0.27 & 0.27 & 0.17 & 0.31 & 0.26 \\
\hline Total Crude Oil Supply & 13.01 & 13.83 & 13.94 & 13.66 & 13.13 & 14.10 & 14.21 & 13.85 & 13.27 & 13.88 & 14.21 & 13.97 & 13.61 & 13.83 & 13.83 \\
\hline \multicolumn{16}{|l|}{ Other Supply } \\
\hline NGL Production & 1.77 & 1.76 & 1.74 & 1.67 & 1.65 & 1.71 & 1.73 & 1.77 & 1.74 & 1.71 & 1.71 & 1.75 & 1.74 & 1.71 & 1.73 \\
\hline Other & 0.33 & 0.21 & 0.22 & 0.26 & 0.26 & 0.24 & 0.25 & 0.27 & 0.33 & 0.34 & 0.34 & 0.34 & 0.25 & 0.25 & 0.34 \\
\hline Crude $\mathrm{C}$ & 0.01 & 0.01 & 0.01 & 0.01 & 0.01 & 0.01 & 0.01 & 0.01 & 0.01 & 0.01 & 0.01 & 0.01 & 0.01 & 0.01 & 0.01 \\
\hline Proce & 0.78 & 0.73 & 0.78 & 0.76 & 0.70 & 0.80 & 0.80 & 0.78 & 0.74 & 0.78 & 0.80 & 0.79 & 0.76 & 0.77 & 0.78 \\
\hline Net Prod & 0.86 & 0.86 & 1.05 & 0.94 & 1.26 & 1.10 & 0.99 & $\therefore .27$ & 1.21 & 1.13 & 0.94 & 1.16 & 0.93 & 1.16 & 1.11 \\
\hline duct Imports ${ }^{\mathrm{C}}$ & 1.77 & 1.77 & 1.89 & 1.91 & 2.08 & 2.03 & 1.88 & 2.24 & 2.14 & 2.02 & 1.81 & 2.13 & 1.83 & 2.06 & 2.02 \\
\hline Produc & 0.90 & 0.91 & 0.84 & 0.97 & 0.83 & 0.93 & 0.89 & 0.97 & 0.94 & 0.89 & 0.87 & 0.97 & 0.90 & 0.90 & 0.92 \\
\hline Product Stock Withdrawn or Added $(-)^{d} \ldots$ & 0.26 & -0.62 & -0.30 & 0.37 & 0.83 & -0.51 & -0.34 & 0.01 & 0.62 & -0.45 & -0.17 & 0.06 & -0.07 & -0.01 & 0.01 \\
\hline Total Supply & 17.02 & 16.79 & 17.44 & 17.68 & 17.82 & 17.45 & 17.66 & 17.97 & 17.92 & 17.40 & 17.84 & 18.08 & 17.24 & 17.72 & 17.81 \\
\hline \multicolumn{16}{|l|}{ Demand } \\
\hline Motor Gasoline & 7.04 & 7.57 & 7.75 & 7.53 & 7.19 & 7.66 & 7.84 & 7.57 & 7.40 & 7.64 & 7.90 & 7.68 & 7.48 & 7.57 & 7.65 \\
\hline & 1.46 & 1.45 & 1.49 & 1.48 & 1.51 & 1.47 & 1.53 & 1.56 & 1.51 & 1.51 & 1.55 & 1.53 & 1.47 & 1.52 & 1.52 \\
\hline Distill & 3.33 & 2.83 & 2.82 & 3.19 & 3.53 & 3.05 & 2.91 & 3.32 & 3.61 & 3.08 & 2.96 & 3.35 & 3.04 & 3.20 & 3.25 \\
\hline Residt & 1.08 & 0.99 & 1.07 & 1.18 & 1.24 & 1.02 & 1.00 & 1.15 & 1.16 & 1.05 & 1.01 & 1.13 & 1.08 & 1.10 & 1.09 \\
\hline Other Oils & 4.10 & 3.95 & 4.31 & 4.31 & 4.35 & 4.25 & 4.38 & 4.37 & 4.25 & 4.13 & 4.41 & 4.40 & 4.17 & 4.34 & 4.30 \\
\hline Total Demand . & 17.02 & 16.79 & 17.44 & 17.68 & 17.82 & 17.45 & 17.66 & 17.97 & 17.92 & 17.40 & 17.84 & 18.08 & 17.24 & 17.72 & 17.81 \\
\hline Total Petroleum Net Imports & 7.04 & 7.73 & 7.82 & 7.88 & 7.38 & 8.09 & 8.36 & 8.13 & 7.65 & 8.15 & 8.41 & 8.35 & 7.62 & 7.99 & 8.14 \\
\hline \multicolumn{16}{|l|}{ Closing Stocks (million barrels) } \\
\hline Crude C:I (excluding SPA) ${ }^{\prime}$. & 337 & 352 & 321 & 335 & 338 & 327 & 331 & 327 & 337 & 335 & 33 & 333 & 335 & 327 & 333 \\
\hline Tote & 230 & 221 & 208 & 226 & 214 & 214 & 202 & 223 & 223 & 218 & 203 & 221 & 226 & 223 & 221 \\
\hline Finished & 189 & 184 & 171 & 187 & 176 & 177 & 164 & 183 & 183 & 180 & 164 & 182 & 187 & 183 & 182 \\
\hline Components. & 41 & 37 & 37 & 39 & 38 & 37 & 38 & 39 & 40 & 38 & 39 & 39 & 39 & 39 & 39 \\
\hline Jet Fuel ....... & 42 & 45 & 41 & 40 & 38 & 41 & 39 & 43 & 44 & 44 & 43 & 46 & 40 & 43 & 46 \\
\hline Distillate Fuel Oil & 97 & 110 & 131 & 141 & 100 & 117 & 134 & 142 & 100 & 104 & 124 & 137 & 141 & 142 & 137 \\
\hline Residual Fuel Oil & 40 & 46 & 44 & 44 & 41 & 40 & 42 & 46 & 40 & 41 & 42 & 45 & 44 & 46 & 45 \\
\hline Other Olls ${ }^{\circ} \ldots$ & 265 & 310 & 334 & 273 & 257 & 284 & 310 & 273 & 264 & 305 & 316 & 272 & 273 & 273 & 272 \\
\hline Total Stocks (exctuding SPR) & 1013 & 1084 & 1080 & 1060 & 987 & 1023 & 1058 & 1054 & 1008 & 1046 & 1064 & 1055 & $\begin{array}{r}1060 \\
587\end{array}$ & 1054 & $\begin{array}{r}1055 \\
599\end{array}$ \\
\hline & 578 & 583 & 586 & 587 & 590 & 592 & 593 & 594 & 595 & 596 & 598 & 599 & 587 & 594 & 599 \\
\hline Total Stocks (including SPR) & 1590 & 1667 & 1665 & 1647 & 1578 & 1615 & 1651 & 1648 & 1603 & 1643 & 1662 & 1653 & 1647 & 1648 & 1653 \\
\hline
\end{tabular}

\footnotetext{
- Includes lease condensate.

- Net imports equals gross imports plus SPR imports minus exports.

- Includes finished petroleum products, unfinished oils, gasoline blending components, and natural gas plant liquids for processing.

- Includes an estimate of minor product stock change based on monthly data.

- Includes crude oll product supplied, natural gas liquids, liquefied refinery gas, other liquids, and all finished petroleum products except motor gasoline, jet fuel, distillate, and residual fuel oil.

'Includes crude oil in transit to refineries.

- Includes stocks of all other olls such as aviation gasoline, kerosene, natural gas liquids (including ethane), aviation gasoline blending components, naphtha and other oils for petrochemical feedstock use, special naphthas, lube oils, war, coke, asphalt, road oil, and miscellaneous oils.

SPR: Strategic Petroleum Reserve

NGL: Natural Gas Llquids

Notes: Minor discrepancies with other ElA published historical data are due to rounding. Historical data are printed in bold, forecasts are in italic. The forecasts were generated by simulation of the Short-Term Integrated Forecasting System.

Sources: Historical data: Energy Information Administration, Petroleum Supply Monthly, DOE/EIA-0109(93/01-94/06); and Weekly Petroleum Status Report, DOE/EIA-0208(various issues).
} 
Table 8. U.S. Petroleum Supply and Demand: High World Oll Price Case (Million Barrels per Day, Except Closing Stocks)

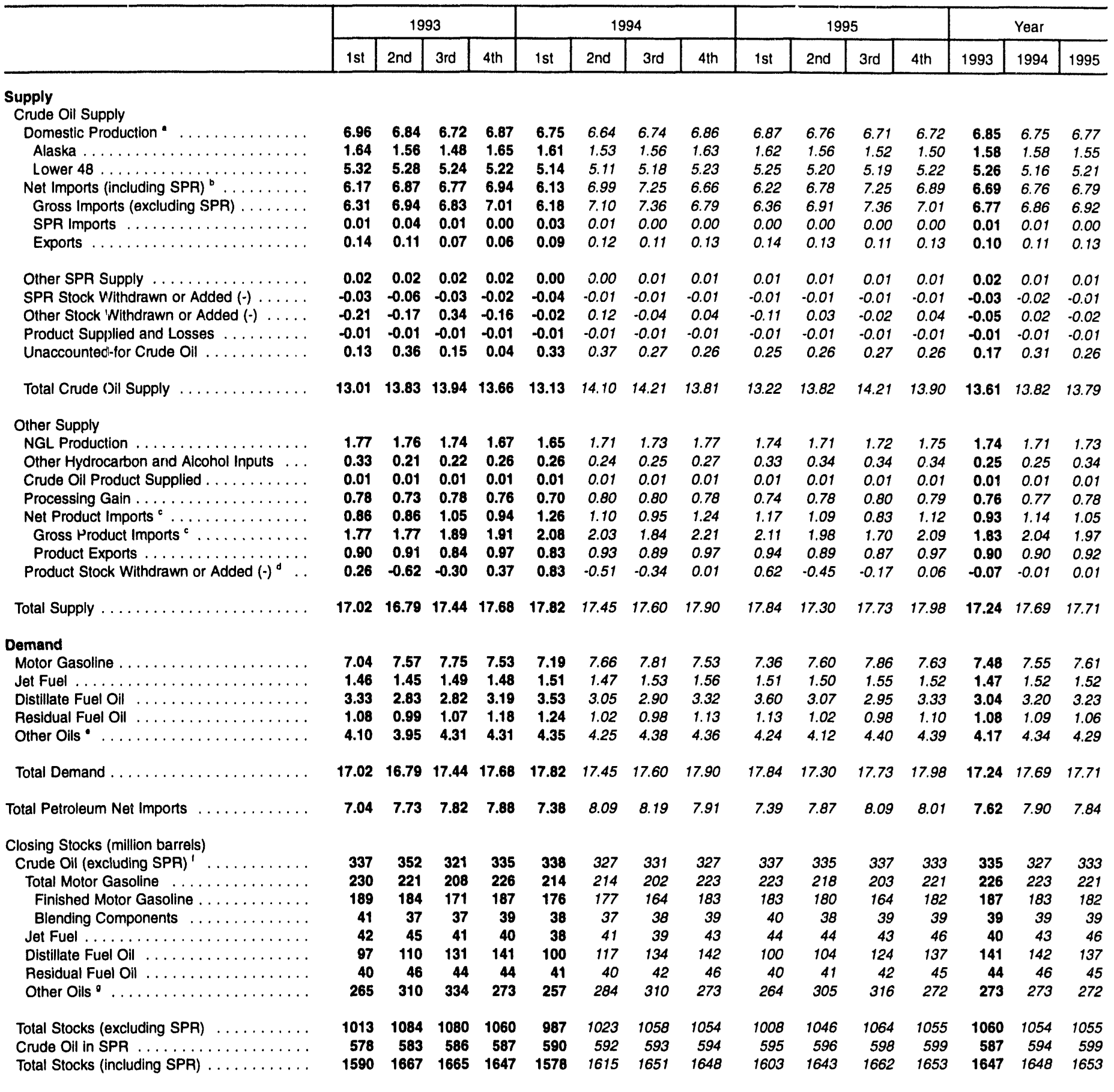

- Includes lease condensate.

' Net imports equals gross imports plus SPR imports minus exports.

- Includes finished petroleum products, unfinished olls, gasoline blending components, and natural gas plant liquids for processing.

- Includes an estimate of minor product stock change based on monthly data.

- Includes crude oil product supplied, natural gas liquids, liquefied refinery gas, other liquids, and all finished petroleum products except motor gasoline, jet fuel, distillate, and residual fuel oil.

' Includes crude oil in transit to refineries.

- Includes stocks of all other oils such as aviation gasoline, kerosene, natural gas liquids (including ethane), aviation gasoline blending components, naphtha and other oils for petrochemical feedstock use, special naphthas, lube olls, wax, coke, asphalt, road oll, and miscellaneous oils.

SPR: Strategic Petroleum Reserve

NGL: Natural Gas Liquids

Notes: Minor discrepancies with other ElA published historical data are due to rounding. Historical data are printed in bold, forecasts are in italic. The forecasts were generated by simulation of the Short-Term Integrated Forecasting System.

Sources: Historical data: Energy Information Administration, Petroleum Supply Monthly, DOE/ElA-0109(93/01-94/06); and Weekly Petroleum Status Report, DOE/EIA-0208(varlous issues). 


\begin{tabular}{|c|c|c|}
\hline & 1994 & 1995 \\
\hline & Two Quarters" & Four Quarters* \\
\hline \multicolumn{3}{|l|}{ Economic Activity } \\
\hline Gross Domestic Product (billion 1987 dollars) $\ldots \ldots \ldots \ldots \ldots$ & $5,336 \cdot 5,391$ & $5,322 \cdot 5,528$ \\
\hline Resulting Change in Petroleum Demand (million barrels per day) ${ }^{b}$ & 0.13 & 0.52 \\
\hline \multicolumn{3}{|l|}{ Energy Prices } \\
\hline Imported Crude Oil (nominal dollars per barrel) ${ }^{c} \ldots \ldots \ldots \ldots$ & $\$ 12.50 \cdot \$ 17.50$ & $\$ 13-\$ 19.90$ \\
\hline \multicolumn{3}{|l|}{ Resulting Change in Petroleum Demand (million barrels per day) ${ }^{b}$} \\
\hline Due to Changes in the Crude Oll Price $\ldots \ldots \ldots \ldots \ldots \ldots$ & -0.17 & -0.20 \\
\hline \multicolumn{3}{|l|}{ Weather } \\
\hline Heating Degree-Days ${ }^{d} \ldots \ldots \ldots \ldots \ldots \ldots \ldots \ldots$ & $16.39 \cdot 19.97$ & $20.28 \cdot 23.99$ \\
\hline Resulting Change in Petroleum Demand (million barrels per day) $\ldots \ldots \ldots \ldots \ldots$ & 0.31 & 0.37 \\
\hline 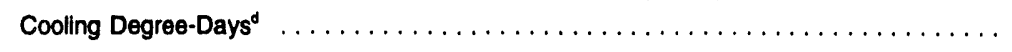 & $7.69-9.17$ & $5.57 \cdot 6.58$ \\
\hline Resulting Change in Petroleum Demand (million barrels per day) ${ }^{b} \ldots \ldots$ & 0.04 & 0.12 \\
\hline
\end{tabular}

- In the weather case, calculations apply to certain quarters only, as follows: for heating degree-days: for 1994, the fourth quarter only is used; for 1995: the average of first and fourth quarters only are used; for cooling degree-days in 1994, the third quarter only is used; in 1995, the average of the second and third quarters is used.

'Ranges of petroleum product supplied associated with varying each determinant (or determinants), holding other things equal.

- Cost of imported crude oil to U.S. refiners.

'Heating and cooling degree-days are U.S. 1990 population-weighted.

Source: Energy Information Administration, Office of Energy Markets and End Use, Energy Markets and Contingency Information Division, Short-Term Integrated Forecasting System.

Table 10. Forecast Components for U.S. Crude Oil Production (Million Barrels per Day)

\begin{tabular}{|c|c|c|c|c|c|}
\hline & \multirow{2}{*}{$\begin{array}{c}\text { High } \\
\text { Price Case }\end{array}$} & \multirow{2}{*}{$\begin{array}{l}\text { Low } \\
\text { Price Case }\end{array}$} & \multicolumn{3}{|c|}{ Difference } \\
\hline & & & Total & Uncertainty & Price Impact \\
\hline United States $\ldots \ldots \ldots \ldots \ldots \ldots \ldots \ldots$ & 6.72 & 6.07 & 0.65 & 0.14 & 0.51 \\
\hline Lower 48 States $\ldots \ldots \ldots \ldots \ldots \ldots \ldots$ & 5.22 & 4.66 & 0.56 & 0.10 & 0.46 \\
\hline Alaska $\ldots \ldots \ldots \ldots \ldots \ldots \ldots \ldots$ & 1.50 & 1.41 & 0.09 & 0.04 & 0.05 \\
\hline
\end{tabular}

Note: Components provided are for the fourth quarter 1995; totals are from Tables 6 and 8 . Totals may not add to sum of components due to independent rounding.

Source: Energy Information Administration, Office of Oil and Gas, Reserves and Natural Gas Division. 
Table 11. U.S. Natural Gas Supply and Demand: Mid World Oil Price Case

(Trillion Cubic Feet)

\begin{tabular}{|c|c|c|c|c|c|c|c|c|c|c|c|c|c|c|c|}
\hline & \multicolumn{4}{|c|}{1993} & \multicolumn{4}{|c|}{1994} & \multicolumn{4}{|c|}{1995} & \multicolumn{3}{|c|}{ Year } \\
\hline & 1st & 2nd & 3rd & 4th & 1 st & 2nd & 3rd & 4th & $1 \mathrm{st}$ & 2nd & 3rd & 4 th & 1993 & 1994 & 1995 \\
\hline \multicolumn{16}{|l|}{ Supply } \\
\hline Total Dry Gas Production ${ }^{\star} \ldots . . .$. & 4.59 & 4.52 & 4.55 & 4.69 & 4.64 & 4.42 & 4.66 & 5.05 & 4.82 & 4.69 & 4.79 & 5.09 & 18.35 & 18.76 & 19.38 \\
\hline Net Imports $\ldots \ldots \ldots \ldots \ldots \ldots \ldots$ & 0.53 & 0.49 & 0.53 & 0.58 & 0.62 & 0.57 & 0.57 & 0.67 & 0.66 & 0.60 & 0.57 & 0.67 & 2.13 & 2.43 & 2.51 \\
\hline Supplemental Gaseous fuels ....... & 0.04 & 0.03 & 0.03 & 0.03 & 0.04 & 0.03 & 0.03 & 0.03 & 0.04 & 0.03 & 0.03 & 0.04 & 0.13 & 0.13 & 0.13 \\
\hline Total New Supply . . . . . . . . . . . & 5.16 & 5.04 & 5.10 & 5.31 & 5.30 & 5.02 & 5.26 & 5.75 & 5.52 & 5.32 & 5.39 & 5.80 & 20.61 & 21.32 & 22.03 \\
\hline \multicolumn{16}{|l|}{ Underground Working Gas Storage } \\
\hline Opening $\ldots \ldots \ldots \ldots \ldots \ldots$ & 6.64 & 5.23 & 6.16 & 7.16 & 6.66 & 5.30 & 6.03 & 6.91 & 6.53 & 5.30 & 6.08 & 7.04 & 6.64 & 6.66 & 6.53 \\
\hline Closing $\ldots \ldots \ldots \ldots \ldots \ldots$ & 5.23 & 6.16 & 7.16 & 6.66 & 5.30 & 6.03 & 6.91 & 6.53 & 5.30 & 6.08 & 7.04 & 6.65 & 6.66 & 6.53 & 6.65 \\
\hline Net Withdrawals ${ }^{b} \ldots \ldots \ldots \ldots$ & 1.41 & -0.93 & -1.00 & 0.50 & 1.36 & -0.73 & -0.88 & 0.38 & 1.23 & .0 .78 & -0.96 & 0.39 & -0.02 & 0.13 & -0.12 \\
\hline Total Supply " . & 6.57 & 4.12 & 4.10 & 5.80 & 6.66 & 4.29 & 4.37 & 6.13 & 6.75 & 4.55 & 4.43 & 6.19 & 20.59 & 21.45 & 21.91 \\
\hline Balancing Item ${ }^{c} \ldots \ldots \ldots \ldots \ldots$ & 0.03 & 0.12 & -0.07 & -0.49 & 0.24 & 0.32 & -0.21 & -0.70 & 0.12 & 0.32 & -0.17 & .0 .66 & -0.41 & -0.35 & -0.39 \\
\hline Total Primary Supply " . & 6.60 & 4.24 & 4.03 & 5.31 & 6.90 & 4.61 & 4.16 & 5.43 & 6.88 & 4.86 & 4.26 & 5.53 & 20.18 & 21.11 & 21.53 \\
\hline \multicolumn{16}{|l|}{ Demand } \\
\hline Lease and Plant Fuel $\ldots \ldots \ldots \ldots$ & 0.30 & 0.30 & 0.30 & 0.31 & 0.30 & 0.30 & 0.30 & 0.31 & 0.32 & 0.30 & 0.30 & 0.31 & 1.20 & 1.21 & 1.23 \\
\hline Pipeline Use . . . . . . . . . . . . . & 0.20 & 0.13 & 0.12 & 0.16 & 0.21 & 0.15 & 0.14 & 0.16 & 0.19 & 0.15 & 0.14 & 0.17 & 0.61 & 0.66 & 0.65 \\
\hline Residential $\ldots \ldots \ldots \ldots \ldots \ldots \ldots$ & 2.31 & 0.85 & 0.39 & 1.41 & 2.44 & 0.92 & 0.44 & 1.34 & 2.32 & 0.99 & 0.45 & 1.37 & 4.96 & 5.15 & 5.12 \\
\hline Commercial $\ldots \ldots \ldots \ldots \ldots$ & 1.20 & 0.54 & 0.36 & 0.80 & 1.29 & 0.54 & 0.37 & 0.77 & 1.22 & 0.58 & 0.36 & 0.78 & 2.81 & 2.97 & 2.95 \\
\hline Industrial $\ldots \ldots \ldots \ldots \ldots \ldots$ & 2.07 & 1.83 & 1.91 & 2.01 & 2.15 & 1.95 & 1.97 & 2.18 & 2.27 & 2.06 & 2.03 & 2.23 & 7.82 & 8.24 & 8.60 \\
\hline Electric Utilities $\ldots \ldots \ldots \ldots \ldots \ldots \ldots$ & 0.52 & 0.60 & 0.95 & 0.62 & 0.51 & 0.76 & 0.95 & 0.67 & 0.55 & 0.78 & 0.98 & 0.67 & 2.68 & 2.89 & 2.98 \\
\hline Total Demand . . . . . . . . . . . . . & 6.60 & 4.24 & 4.03 & 5.31 & 6.90 & 4.61 & 4.16 & 5.43 & 6.88 & 4.86 & 4.26 & 5.53 & 20.18 & 21.11 & 21.53 \\
\hline
\end{tabular}

- Excludes nonhydrocarbon gases removed.

- Net withdrawals may vary from the difference between opening and closing stocks of gas in underground storage due to book transfers between base and working gas categories, and other storage operator revisions of working gas inventories.

c The balancing item represents the difference between the sum of the components of natural gas supply and the sum of components of natural gas demand.

Notes: Minor discrepancies with other ElA published historical data are due to rounding. Historical data are printed in bold, forecasts are in itallc. The forecasts were generated by simulation of the Short-Term Integrated Forecasting System.

Sources: Historical data: Energy Information Administration, Monthly Energy Review, DOE/EIA-0035(94/06); Natural Gas Monthly, DOE/EIA-0130(94/06); and Electric Power Monthly, DOE/EIA-0226(94/05). 
Table 12. U.S. Coal Supply and Demand: Mid World Oil Price Case (Million Short Tons)

\begin{tabular}{|c|c|c|c|c|c|c|c|c|c|c|c|c|c|c|c|}
\hline & \multicolumn{4}{|c|}{1993} & \multicolumn{4}{|c|}{1994} & \multicolumn{4}{|c|}{1995} & \multicolumn{3}{|c|}{ Year } \\
\hline & 1st & 2nd & 3rd & 4th & 1st & 2nd & 3rd & 4 th & $1 s t$ & 2nd & 3rd & 4 th & 1993 & 1994 & 1995 \\
\hline \multicolumn{16}{|l|}{ Supply } \\
\hline $\begin{array}{l}\text { Production } \ldots \ldots \ldots \ldots \ldots \ldots \\
\text { Primary Stock Levels }\end{array}$ & 242.0 & 234.8 & 227.7 & 239.3 & 254.7 & 259.1 & 254.8 & 254.3 & 256.0 & 253.2 & 258.3 & 261.4 & 943.8 & 1023.0 & 1028.8 \\
\hline Opening $\ldots \ldots \ldots \ldots \ldots \ldots \ldots$ & 34.0 & 38.3 & 34.8 & 27.2 & 25.3 & 34.1 & 34.0 & 33.0 & 32.0 & 34.0 & 33.0 & 32.0 & 34.0 & 25. & 32.0 \\
\hline Closing $\ldots \ldots \ldots \ldots \ldots \ldots$ & 38.3 & 34.8 & 27.2 & 25.3 & 34.1 & 34.0 & 33.0 & 32.0 & 34.0 & 33.0 & 32.0 & 32.0 & 25.3 & 32.0 & 32.0 \\
\hline Net Withdrawals . . . . . . . . . . & -4.3 & 3.5 & 7.6 & 1.9 & -8.8 & 0.1 & 1.0 & 1.0 & -2.0 & 1.0 & 1.0 & 0.0 & 8.7 & -6.7 & 0.0 \\
\hline Imports $\ldots \ldots \ldots \ldots \ldots \ldots$ & 1.2 & 1.1 & 2.1 & 2.9 & 1.8 & 1.7 & 1.7 & 1.8 & 1.7 & 1.7 & 1.8 & 1.8 & 7.3 & 7.0 & 6.9 \\
\hline Exports $\ldots \ldots \ldots \ldots \ldots \ldots \ldots$ & 18.9 & 19.9 & 18.5 & 17.2 & 14.9 & 16.5 & 17.0 & 17.3 & 18.6 & 19.2 & 18.3 & 19.2 & 74.5 & 65.8 & 75.4 \\
\hline Total Net Domestic Supply & 220.0 & 219.4 & 219.0 & 226.9 & 232.8 & 244.4 & 240.5 & 239.8 & 237.0 & 236.6 & 242.7 & 244.0 & 885.3 & 957.5 & 960.4 \\
\hline \multicolumn{16}{|l|}{ Secondary Stock Levels ${ }^{\circ}$} \\
\hline Opening $\ldots \ldots \ldots \ldots \ldots \ldots$ & 163.7 & 152.7 & 154.8 & 121.9 & 120.5 & 113.5 & 134.3 & 131.7 & 131.7 & 128.9 & 138.1 & 132.8 & 163.7 & 120.5 & 131.7 \\
\hline Closing $\ldots \ldots \ldots \ldots \ldots$ & 152.7 & 154.8 & 121.9 & 120.5 & 113.5 & 134.3 & 131.7 & 131.7 & 128.9 & 138.1 & 132.8 & 135.4 & 12.0 .5 & 131.7 & 135.4 \\
\hline Net Withdrawals $\ldots \ldots \ldots \ldots \ldots$ & 11.0 & -2.2 & $\mathbf{3 3 . 0}$ & 1.4 & 6.9 & -20.7 & 2.6 & 0.0 & 2.8 & -9.3 & 5.4 & -2.6 & 43.2 & .11 .2 & -3.8 \\
\hline Total Supply & 231.1 & 217.2 & 252.0 & 228.3 & 239.7 & 223.6 & 243.1 & 239.8 & 239.8 & 227.4 & 248.1 & 241.3 & 928.6 & 946.3 & 956.6 \\
\hline \multicolumn{16}{|l|}{ Demand } \\
\hline Coke Plants & 7.8 & 7.9 & 8.0 & 7.7 & 7.4 & 7.5 & 7.7 & 7.6 & 7.5 & 7.7 & 7.8 & 7.7 & 31.3 & 30.3 & 30.7 \\
\hline Electric Utilities $\ldots \ldots \ldots \ldots \ldots \ldots$ & 200.3 & 187.7 & 223.1 & 202.3 & 207.9 & 196.7 & 216.3 & 210.3 & 210.6 & 200.2 & 221.4 & 212.0 & 813.5 & 831.1 & 844.2 \\
\hline Retail and General Industry ${ }^{c} \ldots \ldots$ & 21.0 & 19.3 & 18.8 & 22.0 & 21.6 & 19.5 & 19.1 & 21.9 & 21.7 & 19.4 & 18.8 & 21.7 & 81.0 & 82.1 & 81.7 \\
\hline Total Demand $\ldots \ldots \ldots \ldots \ldots$ & 229.0 & 214.9 & 249.9 & 232.0 & 236.9 & 223.6 & 243.1 & 239.8 & 239.8 & 227.4 & 248.1 & 211.3 & 925.8 & 943.5 & 956.6 \\
\hline Discrepancy $^{d} \ldots \ldots \ldots \ldots$ & 2.0 & 2.4 & 2.1 & -3.6 & 2.8 & 0.0 & 0.0 & 0.0 & 0.0 & 0.0 & 0.0 & 0.0 & 2.7 & 2.8 & 0.0 \\
\hline
\end{tabular}

- Primary stocks are held at the mines, preparation plants, and distribution points.

b Secondary stocks are held by users.

' Synfuels plant demand in 1992 was 1.7 million tons per quarter, and is assumed to remain at that level in 1993, 1994, and 1995.

'Historical period discrepancy reflects an unaccounted-for shipper and receiver reporting difference.

Notes: Rows and columns may not add due to independent rounding. Zeros indicate amounts of less than $500,0 \mathrm{co}$ tons. Historical data are printed in bold, forecasts are in italic. The forecasts were generated by simulation of the Short-Term Integrated Forecasting System.

Sources: Historical data: Energy Information Administration, Monthly Energy Review, DOE/EIA-0035(94/06); and Quarterly Coal Report, DOE/EIA-0221(93/4Q). 
Table 13. U.S. Electricity Supply and Demand: Mid World Oil Price Case (Billion Kilowatthours)

\begin{tabular}{|c|c|c|c|c|c|c|c|c|c|c|c|c|c|c|c|}
\hline & \multicolumn{4}{|c|}{1993} & \multicolumn{4}{|c|}{1994} & \multicolumn{4}{|c|}{1995} & \multicolumn{3}{|c|}{ Year } \\
\hline & $1 s t$ & 2nd & 3rd & 4th & $1 s t$ & 2nd & 3rd & 4 th & $1 s t$ & 2nd & 3rd & 4 th & 1993 & 1994 & 1995 \\
\hline \multicolumn{16}{|l|}{ Supply } \\
\hline \multicolumn{16}{|l|}{ Net Uttlity Generation } \\
\hline Coal $\ldots \ldots \ldots$ & 404.8 & 378.7 & 448.6 & 407.0 & $\mathbf{4 1 7 . 4}$ & 395.1 & 433.0 & 424.1 & 425.1 & 405.0 & 443.6 & 426.9 & 1639.2 & 1669.6 & 1700.6 \\
\hline Petroleum ...... & 22.7 & 18.3 & 33.1 & 25.4 & 32.2 & 26.0 & 28.0 & 24.6 & 29.3 & 25.8 & 28.3 & 24.2 & 99.5 & 110.8 & 107.5 \\
\hline$\ldots \ldots \ldots \ldots \ldots$ & 50.4 & 56.9 & 90.8 & 60.7 & 49.6 & 73.2 & 90.1 & 62.9 & 52.4 & 73.7 & 92.3 & 63.2 & 258.9 & 275.8 & 281.6 \\
\hline Nuclear .... & 157.0 & 146.2 & 162.7 & 144.4 & 154.6 & 145.4 & 171.5 & 150.4 & 156.9 & 138.4 & 168.9 & 155.5 & 610.3 & 622.0 & 619.8 \\
\hline Hydroelectric $\ldots \ldots \ldots \ldots \ldots \ldots$ & 67.8 & 81.1 & 60.3 & $\mathbf{5 5 . 9}$ & 61.1 & 72.3 & 59.4 & 59.5 & 69.0 & 74.3 & 63.1 & 62.9 & 265.1 & 252.3 & 269.3 \\
\hline Geothermal and Other ${ }^{\circ} \ldots \ldots \ldots$ & 2.5 & 2.2 & 2.4 & 2.4 & 2.3 & 2.2 & 2.3 & 2.2 & 2.1 & 2.1 & 2.1 & 2.1 & 9.6 & 9.0 & 8.4 \\
\hline Subtotal $\ldots \ldots \ldots \ldots \ldots \ldots$ & 705.2 & 683.4 & 798.0 & 695.9 & 717.2 & 714.2 & 784.2 & 723.8 & 734.7 & 719.3 & 798.3 & 734.8 & 2882.5 & 2939.5 & 2987.2 \\
\hline Nonutility Generation ${ }^{\circ} \ldots \ldots \ldots \ldots$ & 74.7 & 75.0 & 81.9 & 82.2 & 82.8 & 87.4 & 86.8 & 85.2 & 89.7 & 94.6 & 93.9 & 92.3 & 313.8 & 342.2 & 370.5 \\
\hline Total Generation . . . . . . . . . . . . & 779.9 & 758.4 & 880.0 & 778.1 & 800.0 & 801.6 & 871.0 & 809.1 & 824.4 & 813.9 & 892.3 & 827.1 & 3196.4 & 3281.6 & 3357.7 \\
\hline Net Imports $\ldots \ldots \ldots \ldots \ldots \ldots \ldots$ & 6.2 & 3.7 & 10.2 & 8.7 & 11.4 & 8.2 & 9.8 & 8.6 & 9.0 & 8.3 & 9.7 & 8.5 & 28.7 & 38.1 & 35.5 \\
\hline Total Supply & 786.1 & 762.1 & 890.2 & 786.8 & 811.5 & 809.8 & 880.8 & 817.7 & 833.4 & 822.3 & 902.0 & 835.6 & 3225.1 & 3319.8 & 3393.2 \\
\hline Losses and Unaccounted for ${ }^{c} \ldots \ldots$ & 48.2 & 60.7 & 56.9 & 59.9 & 43.7 & 70.9 & 48.8 & 58.3 & 50.4 & 63.6 & 59.5 & 59.4 & 225.7 & 221.8 & 232.9 \\
\hline \multirow{2}{*}{\multicolumn{16}{|c|}{$\begin{array}{l}\text { Demand } \\
\text { Electric Utility Sales }\end{array}$}} \\
\hline & & & & & & & & & & & & & & & \\
\hline Residential . . . . . . & 260.1 & 210.1 & 292.1 & 231.2 & 273.7 & 231.9 & 280.6 & 242.1 & 270.4 & 236.0 & 279.3 & 248.0 & 993.6 & 1028.3 & 1033.6 \\
\hline Commercial .... & 186.8 & 189.0 & 224.0 & 189.9 & 194.6 & 198.3 & 229.0 & 204.6 & 204.5 & 205.9 & 234.6 & 210.8 & 789.7 & 826.5 & 855.8 \\
\hline Industrial .. & 234.9 & 246.4 & 256.0 & 245.8 & 240.3 & 247.9 & 260.0 & 252.1 & 246.2 & 253.3 & 263.6 & 254.3 & 983.1 & 1000.3 & 1017.5 \\
\hline Other $\ldots \ldots \ldots \ldots \ldots \ldots \ldots$ & 23.4 & 23.1 & 25.4 & 24.0 & 23.6 & 23.3 & 25.2 & 24.0 & 24.0 & 23.6 & 25.3 & 24.0 & 95.9 & 96.1 & 96.9 \\
\hline Subtotal $\ldots \ldots \ldots \ldots \ldots \ldots$ & 705.2 & 668.6 & 797.5 & 691.0 & 732.2 & 701.4 & 794.8 & 722.8 & 745.1 & 718.7 & 802.8 & 737.2 & 2862.3 & 2951.2 & 3003.8 \\
\hline Nonutility Generation for Own Use ${ }^{\circ} \ldots$ & 32.6 & 32.8 & 35.8 & 35.9 & 35.5 & 37.5 & 37.2 & 36.6 & 37.9 & 40.0 & 39.7 & 39.0 & 137.2 & 146.8 & 156.5 \\
\hline Total Demand $\ldots \ldots \ldots \ldots \ldots$ & 737.8 & 701.4 & 833.3 & 726.9 & 767.8 & 738.9 & 832.0 & 759.4 & 783.0 & 758.7 & 842.5 & 776.2 & 2999.4 & 3098.0 & 3160.3 \\
\hline
\end{tabular}

Memo:

Utility Purchases from

Nonutilities ${ }^{b}$

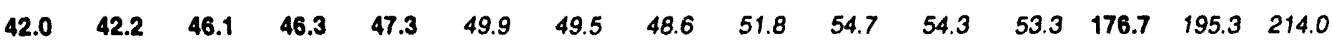

- Other includes generation from wind, wood, waste, and solar sources.

- Total nonutility generation includes electricity output from cogeneration lacilities, independent power producers, and all other types of nonutility facilities. Generation for own use is principally internal use at cogeneration facilties, but may also include some net distribution of electricity by nonutilities to entities other than electric utilities.

'Balancing item, mainly transmission and distribution losses.

Notes: Data for utility purchases from nonutilities, nonutility generation for own use, net imports, total nonutility generation, and losses and unaccounted for are estimated for 1993. Minor discrepancies with other EIA published historical data are due to rounding. Historical data are printed in bold, forecasts are in italic. The forecasts were generated by simulation of the Short-Term Integrated Forecasting System, with projections of nuclear power, hydroelectric generation, net imports and nonutility production being provided exogenously by the Office of Coal, Nuclear, Electric and Alternate Fuels .

Sources: Historical data: Energy Information Administration, Monthly Energy Review, DOE/EIA-0035(94/06); and Electric Power Monthly, DOE/EIA-0226(94/05). 


\section{Computation of Petroleum Demand Sensitivities}

Table 9 summarizes the response of forecasts of U.S. total petroleum demand to changes in assumptions for economic growth, world crude oil prices, and weather. The values in this table are computed using the Short-Term Integrated Forecasting Model (STIFS). The STIFS model is documented in EIA's Short-Term Integrated Forecasting System: 1993 Model Documentation Report (DOE/EIA-M041, May 1993). The purpose of the model is to generate forecasts of U.S. energy supply, demand, and prices. Key inputs include assumptions for the imported price of crude oil, the rate of U.S. economic growth, and weather (cooling and heating degree-days). Forecasts are generated for production, imports, exports, demand, and prices for refined petroleum products, natural gas, coal, and electricity.

A key relationship shown in Table 9 is that between petroleum demand and economic activity. Gross domestic product (GDP) is varied from low to high for each of the two projection years, and the resulting change in petroleum demand is calculated. For each of the 2 years, the percentage difference in GDP is computed as the difference between the low and high case levels shown in Table 2, divided by the midpoint of this range. Thus, the percentage difference in GDP for 1994 (last 2 quarters) is as follows: $((5362+5419) / 2$ $(5338+5333) / 2) /(((5362+5419) / 2+(5338+$ $5333) / 2$ ), or 1.0 percent. For each period, the petroleum demand difference (in million barrels per day) is divided by the percentage difference in GDP. For 1994, the average petroleum demand difference is 130,000 barrels per day; thus, a 1-percent change in GDP corresponds to a change in demand of $(130,000 / 1.0)$, or 130,000 barrels per day. For 1995, a 3.8-percent change in GDP corresponds to a change in demand of 520,000 barrels per day; thus, a 1-percent change in GDP corresponds to a demand change of 137,000 barrels per day. The average of the 1994 and 1995 results (weighting the 1994 by 184 days and 1995 results by 365 days) is 135,000 barrels per day per 1 percent difference in GDP. Table 9 also shows the differences in petroleum demand due to changes in energy prices caused by varying the world crude oil price. The change in petroleum demand (in million barrels per day) is divided by the change in the crude oil price (in dollars per barrel), and the result is averaged over the two projection years to get an estimate of the change in petroleum demand per dollar of change in the crude oil price.

The influence of weather on petroleum demand is also calculated, using the mid-case values for economic activity and imported crude oil prices. The percentage changes in heating or cooling degree-days are computed and divided by the changes in petroleum demand, and the result is averaged over the two projection periods to get an estimate of the change in petroleum demand per 1-percent change in heating and cooling degreedays. The changes in demand due to changes in heating degree-days apply only to the heating season, roughly the first and fourth quarters of the year, while the changes in demand due to changes in cooling degree-days apply only to the cooling season, roughly the second and third quarters of the year. 


\section{Demand, Supply, and Price Outlook for Reformulated Gasoline, 1995}

'Public Law 101-549, Section 211(k), U.S.C. 42, "Clean Air Act Amendments of 1990," enacted on November 15, 1990. Final rule published in Federal Register, Vol. 59 No. 32 (Washington, DC, February 16, 1994), p. 7716 . VOC exclude methane and ethane. TAP are defined as the total mass emissions of benzene, 1,3-butadiene, polycyclic organic matter, formaldehyde, and acetaldehyde.

\section{International Oil Demand}

${ }^{2}$ Energy Information Administration, Office of Energy Markets and End Use, Energy Markets and Contingency Information Division.

\section{International Oil Supply}

${ }^{3}$ Excess capacity data by country provided by Energy Information Administration, Energy Markets and Contingency Information Division.

\section{World Oil Stocks and Net Trade}

4Based on comparison of stocks data for ending 1992 in Energy Information Administration, Petroleum Supply Annual, Volume 1, DOE/EIA-0340(92/1) and estimates for 1993 ending stocks given in Table 7.

\section{U.S. Oil Supply}

${ }^{5}$ Estimate provided by the Energy Information Administration, Reserves and Natural Gas Division.

${ }^{6}$ Energy Information Administration, Office of Oil and Gas.

${ }^{7}$ Drilling rig projections provided by the Energy Information Administration, Reserves and Natural Gas Division.

\section{U.S. Energy Prices}

${ }^{8}$ The gross margins were as follows for refiner diesel fuel: 33.1 cents per gallon for the first 6 months of 1994 compared to 28.9 cents per gallon during the same period 1993. Gross margins are defined, for the purpose of this discussion, as the difference between the refiner price of diesel fuel less the composite refiner acquisition cost of crude oil (CRAC), where the prices and the CRAC are on a per-gallon basis. The CRAC refers to the cost reported in Table 1 in Energy Information Administration, Petroleum Marketing Monthly, DOE/EIA-0380, while the diesel price refers to the price of no. 2 diesel fuel sold through company outlets appearing in Table 15 of the same publication. Temporal aggregations (to quarterly or half-year values) involve monthly quantity weights corresponding to monthly barrels of diesel fuel demand recorded in the third quarter 1994 STIFS database.

'See Energy Information Administration, U.S. Energy Industry Financial Developments, 1994 First Quarter, DOE/EIA0543 (94/1Q).

${ }^{10}$ See Energy Information Administration, Natural Gas Productive Capacity for the Lower 48 States, 1983 through 1995, DOE/EIA-00542 (94). 


\section{Text References and Notes}

\section{U.S. Oil Demand and Supply Sensitivities}

${ }^{11}$ See Natural Gas Productive Capacity for the Lower 48 States, 1983 Through 1995, DOE/EIA-00542(94) for the latest update on U.S. gas capacity. With tighter gas capacity, cold weather scenarios create significantly more in the way of reduced services to interruptible customers and greater switching to fuel oil and other petroleum products for power generation and industrial heat.

\section{U.S. Natural Gas Demand}

${ }^{12}$ Gas Research Institute, "Fuel Switching Issues in the Industrial Sector," 1993.

\section{U.S. Natural Gas Supply}

${ }^{13}$ Energy Innformation Administration, Natural Gas Productive Capacity for the Lowver 48 States, 1980 through 1995, DOE/EIA-00542 (94).

${ }^{14}$ Natural Gas Week, June 13, 1994.

${ }^{15}$ Cited in Natural Gas Intelligence, June 13, 1994.

\section{U.S. Electricity Demand and Supply}

${ }^{16}$ Canadian forecasts of demand are from: Natural Resources Canada, Electric Power in Canada 1992 (Ottawa, Canada, 1993), p. 122. 
The following is a list of references for the figures appearing in this issue of the Short-Term Energy Outlook. Except where noted, all data for figures are taken from datasets containing monthly values of each variable depicted, aggregated to quarterly or annual values as required using appropriate weights. The datasets are created by particular runs of the Short-Term Integrated Forecasting System (STIFS) Model, depending on the scenario or set of scenarios depicted. Also, except when noted, all figures refer to the base or "BBB" case. Other cases referred to are: the high world oil price "BHB"; low world oil price "BLB"; severe weather "BBL"; mild weather "BBS"; strong economic growth "HBB"; weak economic growth "LBB"; weak economic growth with high world oil prices "WHB"; and strong economic growth with low world oil prices "PLB."

1. History: Import cost: Compiled from monthly data for the refiner acquisition cost of imported crude oil used in publication of Energy Information Administration, Petroleum Marketing Annual 1991, DOE/EIA-0487(91) and Petroleum Marketing Annual 1992, DOE/EIA-0487(92), Table 1 for historical series; for recent values, Petroleum Marketing Monthly, DOE /EIA-0380, Table 1; West Texas Intermediate spot price, Oil and Gas Journal Database, June 22, 1994. Projections: Third quarter 1994 STIFS database, BBB, BLB, and BHB cases; and Energy Information Administration, Office of Energy Markets and End Use, Energy Markets and Contingency Information Division.

2. History: Manufacturing Production: Federal Reserve System, Statistical Release G 17; GDP: U.S. Department of Commerce Bureau of Economic Analysis, National Income and Product Accounts of the U.S. Projections: DRI/McGraw-Hill Forecast CONTROL0694, modified by EIA's Office of Integrated Analysis and Forecasting with STIFS energy price forecasts.

3. History: Compiled from annual data used in publication of Energy Information Administration, International Energy Annual, DOE/EIA-0219, Table 8 for historical series; for recent values, International Petroleum Statistics Report, DOE/EIA-0520, Table 2.4; Energy Information Administration, Office of Energy Markets and End Use, Energy Markets and Contingency Information Administration. Projections: Energy Information Administration, Office of Energy Markets and End Use, Energy Markets and Contingency Information Division.

4. History: Compiled from annual data used in publication of Energy Information Administration, International Energy Annual, DOE/EIA-0219, Table 8 for historical series; for recent values, International Petroleum Statistics Report, DOE/EIA-0520, Table 2.4; and Energy Information Administration, Office of Energy Markets and End Use, Energy Markets and Contingency Information Administration. Projections: Energy Information Administration, Office of Energy Markets and End Use, Energy Markets and Contingency Information Division.

5. History: Compiled from annual data used in publication of Energy Information Administration, International Petroleum Statistics Report, DOE/EIA-0520, Table 4.1 for historical series and recent data; and Energy Information Administration, Office of Energy Markets and End Use, Energy Markets and Contingency Information Division. Projections: Energy Information Administration, Office of Energy Markets and End Use, Energy Markets and Contingency Information Division.

6. History: Compiled from annual data used in publication of Energy Information Administration, International Petroleum Statistics Report, DOE/EIA-0520, Table 4.2 for historical series and recent data; 


\section{Figure References}

Energy Information Administration, Office of Energy Markets and End Use, Energy Markets and Contingency Information Administration. Projections: Energy Information Administration, Office of Energy Markets and End Use, Energy Markets and Contingency Information Division.

7. History: Compiled from annual data used in publication of Energy Information Administration, Monthly Energy Review, DOE/EIA-0035, Table 10.3 for historical series and recent data. Projections: Energy Information Administration, Office of Energy Markets and End Use, Energy Markets and Contingency Information Division.

8. History: Compiled from annual data used in publication of Energy Information Administration, International Energy Annual, DOE/EIA-0219, Table 1; Energy Information Administration, Office of Energy Markets and End Use, Energy Markets and Contingency Information Division. Projections: Energy Information Administration, Office of Energy Markets and End Use, Energy Markets and Contingency Information Division.

9. History: Compiled from monthly data used in publication of Energy Information Administration, Petroleum Supply Annual, Volume 1, DOE/EIA-0340/1, Tables S4 through S10; Petroleum Supply Monthly, DOE/EIA-0109, Tables S4 through S10, adjusted in years prior to 1993 for new (1993) reporting basis for fuel ethanol blended into motor gasoline (See Short-Term Energy Outlook, DOE/EIA-0202(93/3Q), Appendix B). Projections: Third quarter 1994 STIFS database, case "BBB."

10. History: Travel: Compiled from monthly data used in the Federal Highway Administration publication, Traffic Volume Trends; Demand: Compiled from monthly data used in publication of Energy Information Administration, Petroleum Supply Annual, Volume 1, DOE/EIA-0340/1, Table S4 for historical series, adjusted for 1993 reporting basis (see note 9 above); for recent values, Petroleum Supply Monthly, DOE/EIA-0109, Table S4; MPG is calculated as Travel (in miles)/Demand (in gallons). Projections: Third quarter 1994 STIFS database, case "BBB."

11. History: Compiled from monthly data used in publication of Energy Information Administration, Petroleum Supply Annual, Volume 1, DOE/EIA-0340/1, Table S1 for historical series; for recent values, Petroleum Supply Monthly, DOE/EIA-0109, Table S1. Projections: Third quarter 1994 STIFS database, cases "BBB," "WHB," and "PLB;" and EIA's Reserves and Natural Gas Division.

12. History: Compiled from monthly data used in publication of Energy Information Administration, Petroleum Supply Annual, Volume 1, DOE/EIA-0340/1, Table S1 for historical series; for recent values, Petroleum Supply Monthly, DOE/EIA-0109, Table S1. Projections: Third quarter 1994 STIFS database, case "BBB." The imports share variable is calculated as the ratio of total net petroleum imports divided by total petroleum demand.

13. History: Compiled from monthly data used in publication of Energy Information Administration, Petroleum Marketing Annual, DOE/EIA-0487, Tables 2, 4, and, 15, for historical series; for recent values, Petroleum Marketing Monthly, DOE/EIA-0380, Tables 2, 4 and 15. Projections: Third quarter 1994 STIFS database.

14. History: Compiled from monthly data used in publication of Energy Information Administration, Petroleum Marketing Annual, DOE/EIA-0487, Tables 2, 4, and, 15, for historical series; for recent values, Petroleum Marketing Monthly, DOE/EIA-0380, Tables 2, 4 and 15. Projections: Third quarter 1994 STIFS database. Gross margins are defined, for the purpose of Figure 14, as the difference between 


\section{Figure References}

the refiner price for a fuel less the composite refiner acquisition cost of crude oil (CRAC), where the prices and the CRAC are on a per-gallon basis. The CRAC refers to the cost reported in Table 1 in Energy Information Administration, Petroleum Marketing Monthly, DOE/EIA-0380. Temporal aggregations (to quarterly values) involve monthly quantity weights corresponding to monthly barrels of refinery production of the respective fuels. Thr average for major products is a weighted average of motor gasoline, number 2 fuel oil, jet fuel and residual fuel oil, where the weights are respective refinery output volumes. Refinery outputs are compiled in the STIFS database from monthly data regularly reported in Energy Information Administration, Petroleum Supply Monthly, DOE/EIA-0109.

15. History: Compiled from monthly data used in publication of Energy Information Administration, Natural Gas Monthly, DOE/EIA-0130, Table 4, and Petroleum Marketing Monthly, DOE/EIA-0380, Table 1, and Monthly Energy Review, DOE/EIA-0035, Table 9.10. Projections: Third quarter 1994 STIFS database.

16. History: Compiled from monthly data used in publication of Energy Information Administration, Natural Gas Monthly, DOE/EIA-0130, Table 4. Projections: Third quarter 1994 STIFS database, cases "BBB," "BLB," and "BHB."

17. History: Compiled from monthly data used in publication of Energy Information Administration, Petroleum Supply Annual, Volume 1, DOE/EIA-0340/1, Table S1 for historical series adjusted for 1993 reporting basis (see note 9 above); for recent values, Petroleum Supply Monthly, DOE/EIA-0109, Table S1. Projections: Third quarter 1994 STIFS database, cases "BBB," "BBS," and "BBL."

18. History: Compiled from monthly data used in publication of Energy Information Administration, Petroleum Supply Annual, Volume 1, DOE/EIA-0340/1, Table S1 for historical series adjusted for 1993 reporting basis (see note 9 above); for recent values, Petroleum Supply Monthly, DOE/EIA-0109, Table S1. Projections: Third quarter STIFS database, cases "BBB," "HBB," and "LBB."

19. History: Compiled from monthly data used in publication of Energy Information Administration, Natural Gas Annual, Volume 2, DOE/EIA-0131, Table 3 for historical series; for recent values, Energy Information Administration, Natural Gas Monthly, DOE/EIA-0130. Projections: Third quarter 1994 database, case "BBB."

20. History: Compiled from monthly data used in publication of Energy Information Administration, Natural Gas Annual, Volume 2, DOE/EIA-0131, Table 3 for historical series; for recent values, Energy Information Administration, Natural Gas Monthly, DOE/EIA-0130. Projections: Third quarter 1994 STIFS database, case "BBB."

21. History: Production and net imports of natural gas compiled from monthly data used in publication of Energy Information Administration, Natural Gas Annual, Volume 2, DOE/EIA-0131/2, Table 2 for historical series; for recent production data, Natural Gas Monthly, DOE/EIA-U130. Projections: Third quarter 1994 STIFS database, case "BBB."

22. History: Compiled from monthly data used in publication of Energy Information Administration, Natural Gas Annual, Volume 2, DOE/EIA-0131, Table 3 for historical series; for recent values, Energy Information Administration, Natural Gas Monthly, DOE/EIA-0130. Projections: Third quarter 1994 STIFS database, case "BBB." 


\section{Figure References}

23. History: Compiled from quarterly data used in publication of Energy Information Administration, Quarterly Coal Report, DOE/EIA-0121, Table 45. Projections: Third quarter 1994 STIFS database, case "BBB."

24. History: Compiled from quarterly data used in publication of Energy Information Administration, Quarterly Coal Report, DOE/EIA-0121, Table 1. Projections: Third quarter 1994 STIFS database, case "BBB"; and Energy Information Administration, Office of Coal, Nuclear, Electric and Alternate Fuels.

25. History: Compiled from monthly data used in publication of Energy Information Administration, Electric Power Monthly, DOE/EIA-0226, Table 51. Projections: Third quarter 1994 STIFS database, case "BBB."

26. History: Compiled from monthly data used in publication of Energy Information Administration, Electric Power Monthly, DOE/EIA-0226, Table 3 and Form EIA-759. Projections: Third quarter 1994 STIFS database, case "BBB"; and Energy Information Administration, Office of Coal, Nuclear, Electric and Alternate Fuels for hydroelectric and nuclear power forecasts. 

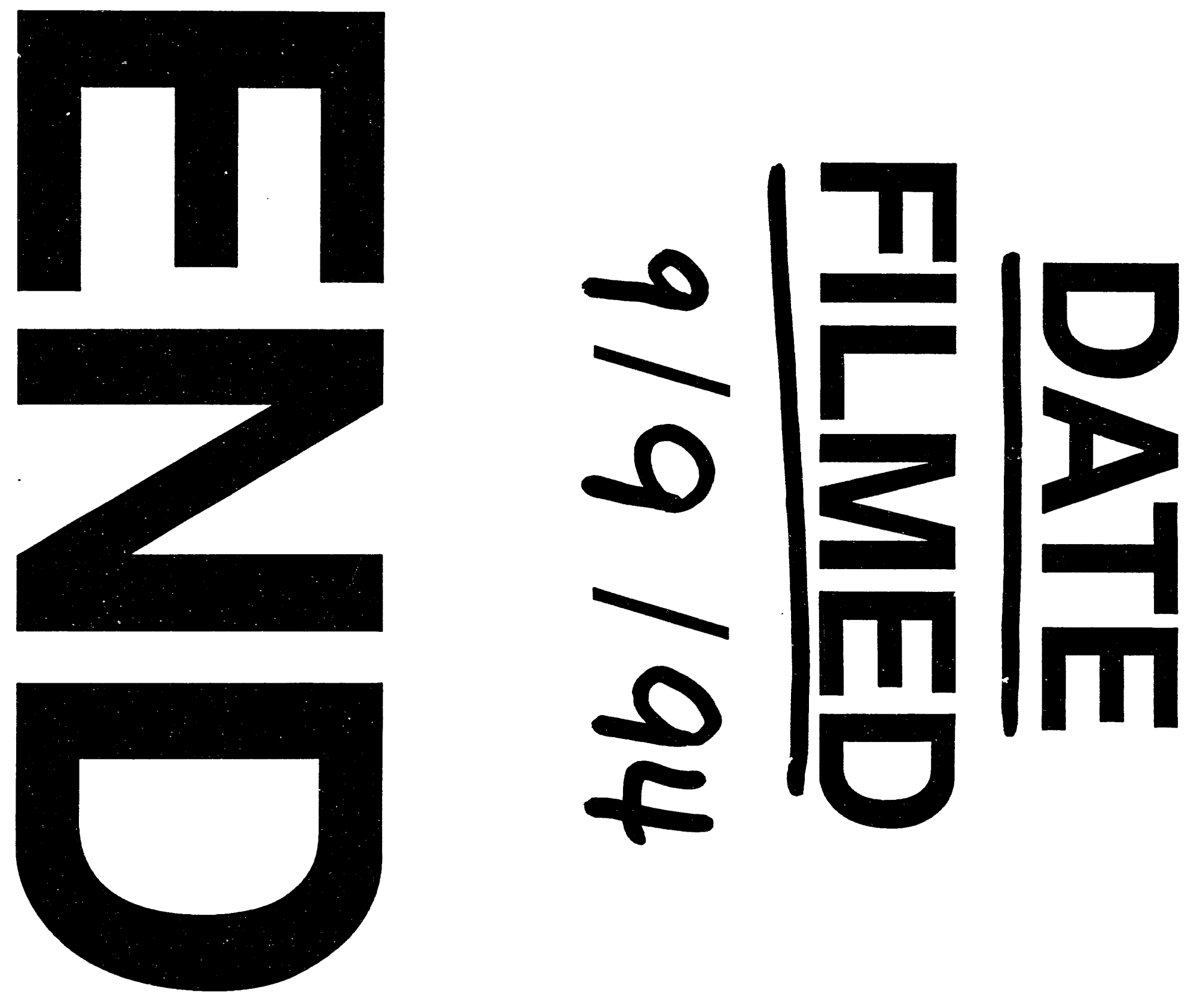


\section{1}

